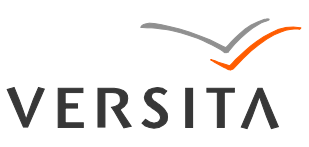

GEOCHRONOMETRIA 39(1) 2012: 84-100

DOI 10.2478/s13386-011-0054-1

Available online at

www.springerlink.com

\title{
NEW EXPOSURE OF LOESS DEPOSITS IN BOYANYCHI (UKRAINE) - RESULTS OF THERMOLUMINESCENCE ANALYSES
}

\author{
JAROSLAW KUSIAK ${ }^{1}$, MARIA LANCZONT ${ }^{\mathbf{1}}$ and ANDRIJ B. BOGUCKI ${ }^{\mathbf{2}}$ \\ ${ }^{I}$ Department of Physical Geography and Palaeogeography, Maria Curie-Skłodowska University, \\ Al. Kraśnicka 2 cd, 20-718 Lublin, Poland \\ ${ }^{2}$ Department of Geomorphology and Palaeogeography, Ivan Franko National University, \\ Doroshenka 41, 79000 Lviv, Ukraine
}

Received 27 May 2010

Accepted 28 September 2011

\begin{abstract}
The loess site at Boynychi (the Volyn Upland) is of essential importance for the stratigraphy of Middle and Upper Pleistocene in Central Europe. The profile was recently dated by Fedorowicz and Prylypko in 2007 (parallel dating), and by Kusiak in 2009. The Upper Vistulian loesses are much thicker in the exposure from 2009 than in the earlier examined one (2007). The list of results obtained in the Gdańsk, Kiev and Lublin laboratories, respectively, can be divided in two. The first group contains the results obtained for the Horohiv and Korshiv pedocomplexes and for the loess from the penultimate glacial, which separates these pedocomplexes. The results from all laboratories are very similar and rather well describe the real age of dated deposits. The second group contains the widely differing results of dating of the Vistulian loesses. The TL ages obtained by Fedorowicz and Prylypko are considerably older than those obtained by Kusiak in the new exposure. The latter ones excellently correspond to the geologic-stratigraphic interpretation of the profile. Two incompatible series of TL dating results indicate that local variability of loess accumulation conditions in different stages of their formation may have resulted in incomplete luminescence zeroing of mineral material before deposition.
\end{abstract}

Keywords: TL dating, loess-soil sequence, Vistulian, penultimate glacial cycle, Volyn Upland.

\section{INTRODUCTION}

The Volyn (Volhynia) Upland forms almost parallel belt about $50 \mathrm{~km}$ wide and $200 \mathrm{~km}$ long; from the north and south it borders on lowland landscapes of the Volyn Polissya and Little Polissya (Fig. 1). Due to the contrast between upland and lowland relief, these geomorphological regions are separated by well-defined in relief orographic boundaries (scarps) of almost rectilinear run and relative height up to several dozens of metres (Bogucki et al., 2007a; Herenczuk et al., 1964). The Volyn Upland is inclined to the north so

Corresponding author: J. Kusiak

e-mail: jaroslaw.kusiak@umcs.lublin.pl the Pripyat River tributaries (western Buh, Styr and Horyn' rivers) flow to the north and their transverse valleys divide the upland into several parts, which are additionally cut by subsequent valleys into plateau-ridges of second rank (Cys', 1962). The Boyanychi (in Polish - Bojanice) profile is situated in the geomorphological subregion known as the Sokal Plateau-ridge, which stretches from the Styr River valley to the Western Buh River and farther to the west on the territory of Poland (Maruszczak, 1972). This undulated plateau occurs between 270-280 and 200-210 m a.s.l., and is diversified by branched systems of dry erosion-denudation valleys and gullies. The valleys' bottoms occur at about $190 \mathrm{~m}$ a.s.l. (Fig. 2). 


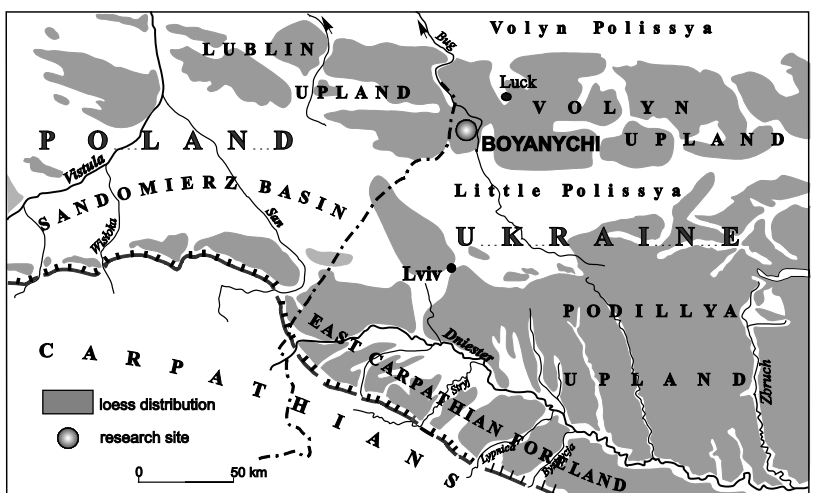

Fig. 1. Location of the Boyanychi site on the background of the loess cover in SE Poland and NW Ukraine.

The Volyn Upland is a typical loess area. Except for the rivers' valleys, it is covered by a loess mantle up to 20-25 m thick. Loess from the Last Glacial is the main part of this cover and overlies the older units. Loess beds are separated by well-developed paleosols of interglacial rank forming pedocomplexes and paleosols that developed during lower-rank warmings. Within loess series there occur periglacial horizons in the form of solifluction and cryoturbation structures as well as thermal contraction structures such as cryogenic wedges with primary mineral infilling and ice wedge casts.

The profile of loess deposits is exposed in a large (almost $1 \mathrm{~km}^{2}$ in area) surface excavation, in which loam is exploited for a brickyard in the town Sokal situated at a distance of $9 \mathrm{~km}$. This excavation is situated in the watershed area between two small rivers flowing to the Western Buh in the east. The Boyanychi profile is of essential importance for loess stratigraphy not only in the Volyn Upland but in the whole East European loess province. It is considered to be a stratotype profile due to the occurrence of loess-soil sequence with 4 pedocomplexes of interglacial rank, which is underlain by till from the San 2 (=Oka, =Elsterian) Glacial. The oldest of these paleosols, corresponding to the Mazovian Interglacial, is developed directly on the glacial deposits. This soil is named Sokal Soil in the regional stratigraphic scheme of the western Ukraine (Bogucki 1986) and Zavadivka according to the Ukrainian Geological Survey (Gozhik et al. 1995, Veklich 1993). The remains of older loesses, divided into two units by a series of fluvial interglacial (Ferdynandovian?) deposits, occur under this moraine and directly overlie the Cretaceous deposits (Bogucki et al., 1994; Lindner et al., 1998; Lindner et al., 2004).

The profile at Boyanychi has been examined for almost 30 years (by e.g., Bogucki et al., 1980; Bogucki, 1986). Basic and several specialist investigations were made, such as mineralogical, magnetic susceptibility and palaeobiological analyses as well as thermoluminescence dating (Szelkoplyas et al., 1985; Bogucki et al., 1995; Szelkoplyas and Christoforowa, 1987; Chlebowski et al.,

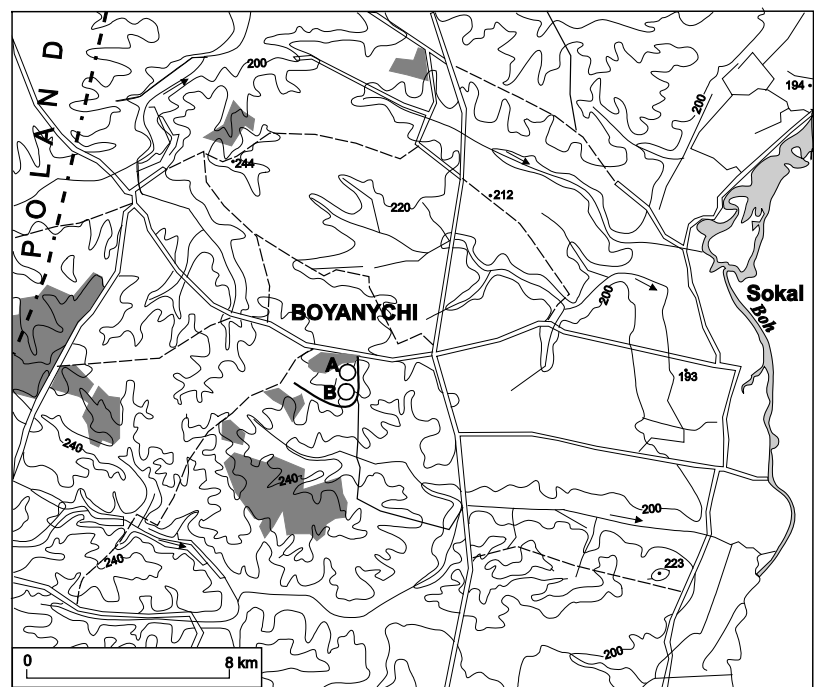

Fig. 2. Topographical sketch of the Boyanychi site environs with location of research points: $A$ - new site, $B$ - old site.

2002, 2003). The distinguished loess units were correlated with the Pleistocene main stratigraphic units in western and mideastern Europe (e.g., Maruszczak, 1994; Lindner et al., 1998; Lindner and Marks, 2008).

\section{INTERLABORATORY COMPARISON OF THE THERMOLUMINESCENCE DATING RESULTS}

In the beginning of the history of thermoluminescence dating in Poland there were few cases of parallel dating of the same profile in several laboratories. The first such experiment was conducted in 1987 when the loess samples from the Odonów profile were TL dated in the Lublin, Warsaw and Gliwice laboratories (Bluszcz, 1987; Butrym, 1987; Prószyńska-Bordas et al., 1987). We should also mention the following loess profiles, which were TL dated at different time and in different laboratories:

1) Polanów Samborzecki - the profile was dated by Prószyński in Warsaw and by Butrym in Lublin in 1985, and three times by Kusiak in Lublin in 1997, 2006 and 2008 (Buraczyński, 1995; Grygierczyk and Waga, 1993; Kusiak and Łanczont, 2002; Kusiak, 2006; Kusiak, 2008b);

2) Dubaniewice - the profile was dated by Butrym in Lublin in 1988, by Szelkoplyas in Kiev in 1996 and by Kusiak in Lublin in 2003 (Bogucki et al., 2004);

3) Wąchock - the profile was dated by Prószyński in Warsaw in 1979 (Lindner and Prószyński, 1979) and by Kusiak in Lublin in 1997 (Kusiak, 2008a).

Parallel dating of the Pleistocene deposits from the same sites in several laboratories became more frequent only after 2000. Samples of loess and fluvial deposits from several Polish (Tarnawce, Dybawka Dolna, Dankowice, Biały Kościół), Ukrainian (Halych, Velykyi 
Hlybochok) and Lithuanian (Vilkiškes, Tartokai, Rokai) profiles were TL dated by Fedorowicz and OSL dated by Bluszcz (Fedorowicz, 2006). In the Gdańsk and Lublin laboratories there were also TL dates obtained for the Ukrainian loess profiles (Halych, Velykyi Hlybochok, Yezupil) and for the Zarzecze profile in Poland (Lanczont and Madeyska, 2005; Lanczont and Wojtanowicz, 2005; Łanczont et al., 2009; Bogucki et al., 2009).

The profile of Quaternary deposits at Boyanychi was sampled and TL dated several times. Each sampling was supplemented by detailed description and graphic documentation. The comparison of these data (Fig. 5) indicates that all distinguished stratigraphic units occurred in each of the investigated parts of the excavation but their thickness was different.

A. Bogucki collected two series of samples from the same layers but different parts of the excavation in 1985 and 1992. First TL ages were obtained in Kiev (Szelkoplyas et al., 1985). The second series of samples were dated by J. Butrym in Lublin in 1992 (cf. Lindner and Marks, 2008). In 2007 the Boyanychi profile was presented during the $14^{\text {th }}$ Polish-Ukrainian symposium entitled "Stratigraphic correlation of loess and glacial deposits in Poland and Ukraine" (Bogucki et al., 2007a). S. Fedorowicz from the Gdańsk laboratory and S. Prylypko from the Kiev laboratory were present at this symposium and they collected samples for parallel thermoluminescence dating. The results were published by Fedorowicz et al. (2008).

In 2008 a new wall was exposed in the northern part of the excavation, along the road leading inside it, about $200 \mathrm{~m}$ from the Boyanychi-Varyazh road, in that part of the plateau, which is slightly inclined to the north to the valley of a small river flowing near the Boyanychi village (Fig. 2). In this new wall the Vistulian loesses are much thicker than in other parts of the plateau. The profile was sampled every $0.2 \mathrm{~m}$ for isotopic and grain size analyses. Samples of undisturbed structure for micromorphological analysis and samples for TL dating were collected from the distinctive layers. Moreover, the exposure presented during the symposium in 2007 was sampled again for TL dating in 2008, more specifically, the older part of the profile $(11.20-15.50 \mathrm{~m})$, below the Eemian soil. This "old" part of the excavation was situated quite near the new wall, about $100 \mathrm{~m}$ to the south. In the description the notation of depth is continuous for both parts.

Regional names and stratigraphic symbols from north-western Ukraine (Bogucki, 1986; Bogucki and Łanczont, 2002) and from central Ukraine (Gozhik et al., 1995; Veklich, 1982) were used for soil and loess units (Fig. 5).

Unfortunately, the surface layer with modern soil was removed in the excavation area during the preparations for loam exploitation. That is why the profile description begins from the $\mathrm{C}_{\mathrm{Ca}}$ horizon of the modern soil, according to the state of exposure in 2008 (Table 1).

\section{DESCRIPTION OF DATING METHOD}

The TL age of a deposit is given by the following formula:

$t=E D / D_{r}$

where:

$E D$ - equivalent dose is the laboratory dose of $\beta$ or $\gamma$ radiation, which produces the same thermoluminescence as that produced by the dose absorbed by the examined sample under natural conditions,

$D_{r}-$ dose rate is the effective dose of ionizing radiation absorbed by the examined sample in a ka.

\section{Determination of the equivalent dose $E D$}

Samples for $E D$ determination should be protected from sunlight. In order to do that, samples are taken using about $20 \mathrm{~cm}$ long metal samplers, which are inserted into a deposit. Laboratory preparation of mineral material for measurements is carried out in a darkened room lit only with red light (Kaiser lamp 590). The equivalent dose was determined by the total-bleach method described by Singhvi et al. (1982). From the total mass of each sample the $45-63 \mu \mathrm{m}$ polymineral fraction was separated by wet sieving, and then treated with $10 \% \mathrm{HCl}$ to remove carbonates and with $30 \% \mathrm{H}_{2} \mathrm{O}_{2}$ to remove organic material (Balescu et al., 1991). Then, the mineral material obtained from each sample was divided into six portions. One portion was used to determine the natural thermoluminescence. The second portion was exposed to light from an ultraviolet lamp of OSRAM ULTRA-VITALUX type for about 12 hours, in order to determine the residual level of thermoluminescence. The remaining four portions were irradiated with the ionising radiation doses from a ${ }^{60} \mathrm{Co} \gamma$ source (300 Gy, $500 \mathrm{~Gy}, 1000 \mathrm{~Gy}$ and 2000 Gy). The samples have been preheated for $3 \mathrm{~h}$ at $120^{\circ} \mathrm{C}$ prior to glowing (Berger et al., 1992; Kusiak, ; Kusiak, 2002; Kusiak et al., 2002).

Irradiation of samples (in the Institute of Nuclear Chemistry and Technology, Warszawa, Poland) and thermoluminescence measurements (in Lublin laboratory) were carried out at least a month apart. For this reason, it was not possible to carry out a full test for anomalous fading as described by Huntley and Lamothe (2001). Despite this, after fourteen months the TL measurements were performed again. The obtained results of $E D$ were higher by about 10 per cent. Corrected values of the equivalent dose and TL ages are given in Table 3 and Fig. 5.The glow curves were recorded using a RA'94 TL reader/analyser (with the EMI 9789 QA photomultiplier) produced by Mikrolab Kraków (Poland) linked with an IBM computer. Aliquots are glowed out in argon atmosphere at a heating rate of $10^{\circ} \mathrm{C} / \mathrm{s}$ up $400^{\circ} \mathrm{C}$ ). An optical filter HA-3 was used to cut infra-red radiation of the platinum heater. 
Table 1. Description of the profiles of Quaternary deposits at Boyanychi.

"New" profile, 2008

Depth (m)

0-1.2 S0 - $\mathrm{C}_{\mathrm{Ca}}$ horizon, silty-sandy, buff (10YR8/4), with pseudomycelia and carbonate concretions $3 \mathrm{~cm}$ in diameter, numerous casts of fauna winter holes and crotovinas channels filled with the material from the A horizon, numerous iron-manganese concretions ( $3 \mathrm{~mm}$ in diameter), indistinct stratification and ferruginous streaks are visible in the lower part; calcareous. Sharp boundary.

Boyanychi TL $1-0.6 \mathrm{~m}$

1.2-2.1 Krasyliv horizon (buried active layer of permafrost), silty-sandy, rather compact, buff with bluish tint (10YR7/1), with exceptionally numerous secondary forms of Liesegang ring type $(3 \mathrm{~cm})$, the number of which decreases downwards, with pseudomycelia and rustcoloured iron-manganese concretions $(3 \mathrm{~mm})$, single crotovinas (10 $\mathrm{cm}$ in diameter) are filled with the material from the $B_{\mathrm{ca}}$ horizon; calcareous.

Boyanychi TL $2-1.6 \mathrm{~m}$

2.1-4.8 Silty-sandy loess with laminae of clayey sand, yellowish-grey (10YR7/2), with pseudomycelia, carbonate and iron-manganese concretions, stratified (indistinctly, and distinctly only in places), inclined $\left(10^{\circ}\right)$ as palaeosurface to the east, stratification is accentuated by stronger gleying and ferruginization on sedimentation surfaces. Liesegang rings $(3 \mathrm{~cm}$ in diameter) are distinctly more numerous at a depth of 3.7-4 m, and complex secondary forms occur, which are filled partially with ferruginous material and partially with gleyed material. Distinct boundary. This layer is discontinuous.

Boyanychi TL $3-2.3 \mathrm{~m}$

Boyanychi TL $4-3.3 \mathrm{~m}$

Boyanychi TL 5-4.3 m

4.8-5.8 Rivne horizon, silty-sandy deposit, gleyed and ferruginized, buff (10YR8/3) and bluish-grey (10YR7/2), with very numerous, especially in the upper part, Liesegang rings $2-3 \mathrm{~cm}$ in diameter, with pseudomycelia, single carbonate concretions $3 \mathrm{~cm}$ in diameter, stratified (inclination of $10-15^{\circ}$ to the east), with lenses of yellow clayey sand; calcareous. Distinct boundary.

Boyanychi TL $6-5.2 \mathrm{~m}$

5.8-8.1 Loess, buff (10YR7/2) and grey (gleyed?) (10YR7/1), microporous, indistinctly stratified, with gleying and ferruginization along sedimentation surfaces, with pseudomycelia and carbonate concretions, with numerous small iron-manganese concretions merging into patches in places. Distinct boundary is accentuated by agglomeration of carbonate concretions.

Boyanychi TL $7-6 \mathrm{~m}$

Boyanychi TL $8-7 \mathrm{~m}$

Boyanychi TL $9-8 \mathrm{~m}$

8.2-8.8 Dubno paleosol with varying thickness caused by diversified paleorelief. Silty-clayey deposit, bluish-grey (10YR6/1), stratified (this feature is accentuated by ferruginization), wavy stratification in places, with single, large $(7 \mathrm{~cm})$ Liesegang rings with strongly ferruginous centres. This soil directly overlies the Horokhiv pedocomplex in places.

Boyanychi TL $19-8.5 \mathrm{~m}$

8.8-9.2 Silty-clayey loess, compact, gleyed in the upper part, with numerous, mostly black iron-manganese concretions (4 mm); calcareous. Boyanychi TL $11-9 \mathrm{~m}$

9.2-9.6 Silty-clayey, solifluction layer, bluish- and yellowish-grey (10YR7/3 and 10YR6/1), ferruginized and gleyed, with lenses and tongues of loamy material from the A horizon of the Horokhiv pedocomplex; calcareous, weakly.

Distinct boundary.

Horokhiv pedocomplex (S1), very well developed

9.6-11.2 A horizon (0.25 m thick), silty-clayey, chocolate brown (10YR4/6), in places with rust tint, ferruginized and gleyed, with traces of pedofauna activity, with silica sprinkling in the bottom part; non-calcareous.

Boyanychi TL $12-10.4 \mathrm{~m}$

Eet horizon ( $0.15 \mathrm{~m}$ thick), loamy sand, cocoa brown (10YR7/4) with light spots (4 cm in diameter) (10YR8/12), with numerous charcoals (about $1 \mathrm{~cm}$ ) and iron-manganese concretions $(3 \mathrm{~mm})$; non-calcareous. Distinct boundary. Material from his horizon gets in huge, grey cryogenic wedges reaching $0.3 \mathrm{~m}$ in width and about $1 \mathrm{~m}$ in depth (to the bottom of the Bt horizon).

Boyanychi TL $13-10.6 \mathrm{~m}$

Bt horizon (1.2 m thick), rust-coloured-brown, red-rust-coloured in places (7.5 YR7/6). Cryogenic wedges and numerous vertical, narrow fissures with streaks of ferruginous material occur in this horizon. Traces of pedofauna activity (tunnels $1.5 \mathrm{~cm}$ in diameter) are numerous. Three types of cryogenic wedges were distinguished - black (filled with material from the A horizon), grey (filled with material from the Eet horizon), and red of unclear origin.

Bt1 (0.6 m thick), very compact, strongly gleyed, with post-cryogenic, distinct cellular structure $(0.5 \mathrm{~cm}$ high, $1.0-1.5 \mathrm{~cm}$ wide), in places incompletely reticulate structure; non-calcareous.

Bt2 (0.6 m thick), less compact, with sand lenses, ground ice structure less developed, intense rust-coloured in places; non-calcareous. Distinct boundary.

Boyanychi TL $14-11.0 \mathrm{~m}$ 
Table 1. Continuation

"Old" profile, 2007 (after Bogucki et al., 2007b)

Depth (m)

11.2-11.7 Silty-clayey loess, gleyed, bluish-grey (10YR7/2), with numerous rust-coloured iron-manganese concretions; non-calcareous. TL $20-11.2 \mathrm{~m}$

11.7-12.1 Ternopil horizon - bipartite paleosol.

Humus horizon 0.2 m thick - silty-clayey deposit, bluish-grey, with vertical, narrow, small fissures and very numerous, black, soft ironmanganese concretions $(1 \mathrm{~cm})$; non-calcareous. Distinct boundary.

Bt horizon $0.2 \mathrm{~m}$ thick - silty-sandy deposit, quite homogeneous, yellowish-rust-coloured, with numerous iron-manganese concretions non-calcareous. Gradual transition.

12.1-12.7 Silty-sandy deposit, bluish-grey and light rust-coloured, ferruginized, gleyed, with carbonate dolls, with numerous iron-manganese large and small concretions; calcareous. Distinct boundary.

TL $19-12.4 \mathrm{~m}$

12.7-13.1 Solifluction layer, composed of the loesses and lenses and tongues of material from the humus horizon of the underlying soil.

Korshiv pedocomplex composed of two units of interglacial rank (S2-I and S2-II)

13.1-13.9 Humus horizon of the S2-I soil, sandy loam, dark grey, compact, with traces of pedofauna activity, with lighter tone of colour and silica sprinkling in the lower part; non-calcareous. Single cryogenic wedges, up to $1 \mathrm{~m}$ deep, extend downwards from this horizon.

TL $18-13.4 \mathrm{~m}$

13.9-14.4 Bt horizon $0.5 \mathrm{~m}$ thick, silty-sandy deposit, brown, with silica sprinkling in the upper part, with crumb structure, compact, very numerous black, mostly soft iron-manganese concretions ( $5 \mathrm{~mm}$ in diameter); non-calcareous. Gradual transition.

TL $17-14.1 \mathrm{~m}$

14.4-14.8 Humus horizon of the S2-II soil, silty-clayey, dark brown, with crumb structure, strongly compact, uniform, in places cut by cryogenic wedges connected with the humus horizon of the soil S2-I.

TL $16-14.5 \mathrm{~m}$

14.8-15.5 Bt horizon, silty-clayey, very compact, reddish-rust-coloured, with iron-manganese concretions; non-calcareous. TL $15-15.2 \mathrm{~m}$

The way of reading of the thermoluminescence light sums (i.e. numerical values used for ED determination, which are plotted on the y-axis of the $T L=f(D)$ graph) is very important for the final result of TL dating. In the 1980 s it was commonly accepted that the only right way was to read the TL light sum as the surface area under the glow curve based on the results of the "plateau test". However, in the opinion of Frechen (1992) who dated a great number of samples of similar age taken from loess profiles with well identified stratigraphy, the determination of equivalent dose based on this test can give faulty results, which deviate from the real values even by \pm $100 \%$. This in turn can cause very large errors in the calculation of TL ages. Frechen (1992) states that this phenomenon does not occur if the same surface area under a wide region (about $100^{\circ} \mathrm{C}$, e.g. $300-400^{\circ} \mathrm{C}$ for loess deposits) of the TL glow curve, including the maximum of the curve and often also the plateau area, is used for all samples. However, Kusiak (2006, 2008a), who dated loess deposits from Poland, finds that sometimes also the above-described procedure gives the TL dating results, which are difficult to interpret taking into account the conditions of loess accumulation. Kusiak (2006, 2008a) states that such TL age fluctuations are not observed if the TL light sum is read as the area under the narrow $\left(10^{\circ} \mathrm{C}\right)$ region of the TL glow curve, which includes its maximum.

In order to determine the ED value, about thirty subsamples of $4 \mathrm{mg}$ in weight were taken from each portion. An exponential saturation function was fitted to the ob- tained points with the use of the FIT-SIM programme (Grün, 1994), which was based on the simplex fitting procedures and analytical error calculation described by Brumby (1992).

\section{Determination of dose rate}

Dose rate for the $45-63 \mu \mathrm{m}$ grain fraction was calculated using the following formula:

$D_{r}=k a d_{\alpha}+d_{\beta}+d_{\gamma}+d_{c}$

where

$k=0.1$ indicates the effectiveness of generating thermoluminescence when subjected to $\alpha$ radiation

$a=0.5$ is a correction due to the fact that grains of about $50 \mu \mathrm{m}$ in diameter can receive only $50 \%$ of the $\alpha$ radiation dose received in the same deposit by grains of $10 \mu \mathrm{m}$ and less in diameter (Wintle, 1987);

$d_{o}, d_{\beta}, d_{\gamma}, d_{c}-$ doses from $\alpha, \beta, \gamma$ and cosmic radiation, respectively.

Dose rates $d_{\alpha}, d_{\beta}, d_{\gamma}$ were calculated from the measured concentrations of natural radionuclides $\left({ }^{40} \mathrm{~K},{ }^{226} \mathrm{Ra}\right.$, ${ }^{228} \mathrm{Th}$ ) (Table 2). The measurements were carried out in the laboratory using a three-channel, stationary gamma spectrometer type MAZAR-95 produced by Polon-Zot Warszawa (Poland), assuming age equilibrium state in the radioactive series (Poręba and Fedorowicz, 2005). The measurements of radioisotopes were carried out for the deposit portions of about $2000 \mathrm{~g}$ in weight in Marinelli-type containers. All samples were measured be- 
Table 2. A summary of radioactive isotopes content, as determined by gamma spectrometry in the laboratory and the dose rate.

\begin{tabular}{|c|c|c|c|c|c|c|c|}
\hline $\begin{array}{c}\text { Depth } \\
\text { (m) }\end{array}$ & Lab. No & Water content & $\begin{array}{c}{ }^{40} \mathrm{~K} \\
(\mathrm{~Bq} / \mathrm{kg})\end{array}$ & $\begin{array}{c}{ }^{226} \mathrm{Ra} \\
(\mathrm{Bq} / \mathrm{kg})\end{array}$ & $\begin{array}{c}228 \mathrm{Th} \\
(\mathrm{Bq} / \mathrm{kg})\end{array}$ & $\begin{array}{l}\text { Cosmic } \\
\text { (Gy/ka) }\end{array}$ & $\begin{array}{c}\text { Dose rate } \\
\text { (Gy/ka) }\end{array}$ \\
\hline 0.60 & Lub-4710 & $15 \pm 5$ & $433 \pm 35$ & $29.4 \pm 4.7$ & $29.3 \pm 2.6$ & $0.20 \pm 0.01$ & $3.01 \pm 0.29$ \\
\hline 1.60 & Lub-4711 & $15 \pm 5$ & $457 \pm 23$ & $23.5 \pm 2.4$ & $32.6 \pm 1.7$ & $0.18 \pm 0.01$ & $3.01 \pm 0.21$ \\
\hline 2.30 & Lub-4712 & $15 \pm 5$ & $415 \pm 33$ & $29.7 \pm 4.7$ & $29.3 \pm 2.6$ & $0.17 \pm 0.01$ & $2.97 \pm 0.35$ \\
\hline 3.30 & Lub-4713 & $15 \pm 5$ & $443 \pm 35$ & $27.9 \pm 4.5$ & $31.6 \pm 2.8$ & $0.16 \pm 0.01$ & $3.04 \pm 0.32$ \\
\hline 4.30 & Lub-4714 & $15 \pm 5$ & $442 \pm 35$ & $30.5 \pm 4.9$ & $29.9 \pm 2.7$ & $0.14 \pm 0.01$ & $3.07 \pm 0.30$ \\
\hline 5.20 & Lub-4715 & $15 \pm 5$ & $422 \pm 34$ & $29.2 \pm 4.7$ & $32.3 \pm 2.9$ & $0.13 \pm 0.01$ & $3.01 \pm 0.29$ \\
\hline 6.00 & Lub-4716 & $15 \pm 5$ & $466 \pm 37$ & $27.4 \pm 4.4$ & $34.9 \pm 3.1$ & $0.13 \pm 0.01$ & $3.07 \pm 0.29$ \\
\hline 7.00 & Lub-4717 & $15 \pm 5$ & $432 \pm 35$ & $27.3 \pm 4.4$ & $32.5 \pm 2.9$ & $0.12 \pm 0.01$ & $3.00 \pm 0.29$ \\
\hline 8.00 & Lub-4718 & $15 \pm 5$ & $414 \pm 33$ & $33.1 \pm 5.3$ & $31.7 \pm 2.8$ & $0.11 \pm 0.01$ & $3.08 \pm 0.30$ \\
\hline 8.50 & Lub-4719 & $15 \pm 5$ & $455 \pm 36$ & $34.3 \pm 5.5$ & $34.3 \pm 3.0$ & $0.10 \pm 0.01$ & $3.20 \pm 0.31$ \\
\hline 9.00 & Lub-4720 & $15 \pm 5$ & $450 \pm 36$ & $30.3 \pm 4.8$ & $35.9 \pm 3.2$ & $0.10 \pm 0.01$ & $3.12 \pm 0.31$ \\
\hline 9.70 & Lub-4721 & $15 \pm 5$ & $406 \pm 32$ & $30.8 \pm 4.9$ & $34.4 \pm 3.1$ & $0.09 \pm 0.01$ & $2.97 \pm 0.29$ \\
\hline 9.90 & Lub-4722 & $15 \pm 5$ & $474 \pm 38$ & $27.8 \pm 4.5$ & $37.4 \pm 3.3$ & $0.09 \pm 0.01$ & $3.17 \pm 0.31$ \\
\hline 11.00 & Lub-4723 & $15 \pm 5$ & $445 \pm 22$ & $21.7 \pm 2.2$ & $41.3 \pm 2.2$ & $0.09 \pm 0.01$ & $3.01 \pm 0.21$ \\
\hline 11.20 & Lub-4729 & $15 \pm 5$ & $421 \pm 34$ & $35.4 \pm 5.7$ & $33.1 \pm 2.9$ & $0.09 \pm 0.01$ & $3.10 \pm 0.30$ \\
\hline 12.40 & Lub-4728 & $15 \pm 5$ & $439 \pm 22$ & $28.1 \pm 2.9$ & $32.5 \pm 1.7$ & $0.08 \pm 0.01$ & $2.93 \pm 0.21$ \\
\hline 13.40 & Lub-4727 & $15 \pm 5$ & $396 \pm 32$ & $31.0 \pm 5.0$ & $31.9 \pm 2.8$ & $0.07 \pm 0.01$ & $2.88 \pm 0.28$ \\
\hline 14.10 & Lub-4726 & $15 \pm 5$ & $452 \pm 23$ & $24.5 \pm 2.5$ & $38.0 \pm 2.0$ & $0.07 \pm 0.01$ & $3.02 \pm 0.21$ \\
\hline 14.50 & Lub-4725 & $15 \pm 5$ & $430 . \pm 34$ & $29.2 \pm 4.7$ & $35.8 \pm 3.2$ & $0.07 \pm 0.01$ & $3.03 \pm 0.29$ \\
\hline 15.20 & Lub-4724 & $15 \pm 5$ & $456 \pm 36$ & $23.4 \pm 3.7$ & $37.5 \pm 3.3$ & $0.06 \pm 0.01$ & $2.99 \pm 0.29$ \\
\hline
\end{tabular}

Table 3. New TL dates of deposits from the Boyanychi profile.

\begin{tabular}{|c|c|c|c|c|c|}
\hline Lab. No & $\begin{array}{c}\text { Dose rate } \\
\text { (Gy/ka) }\end{array}$ & $\begin{array}{c}\text { Uncorrected } \\
\text { equivalent dose ED } \\
(\mathrm{Gy})\end{array}$ & $\begin{array}{l}\text { Uncorrected } \\
\text { TL age } \\
\text { (ka) }\end{array}$ & $\begin{array}{c}\text { Corrected } \\
\text { equivalent dose ED } \\
(G y)\end{array}$ & $\begin{array}{c}\text { Corrected } \\
\text { TL age } \\
\text { (ka) }\end{array}$ \\
\hline Lub-4710 & $3.01 \pm 0.29$ & $45 \pm 4$ & $15.0 \pm 2.0$ & $48.6 \pm 3.6$ & $16.1 \pm 1.9$ \\
\hline Lub-4711 & $3.01 \pm 0.21$ & $45 \pm 2$ & $15.0 \pm 1.2$ & $47.7 \pm 3.2$ & $15.8 \pm 1.5$ \\
\hline Lub-4712 & $2.97 \pm 0.35$ & $44 \pm 3$ & $15.0 \pm 2.0$ & $48.5 \pm 4.1$ & $16.3 \pm 2.4$ \\
\hline Lub-4713 & $3.04 \pm 0.32$ & $45 \pm 3$ & $15.0 \pm 1.8$ & $48.4 \pm 2.8$ & $15.9 \pm 1.9$ \\
\hline Lub-4714 & $3.07 \pm 0.30$ & $50 \pm 3$ & $16.0 \pm 1.8$ & $53.4 \pm 3.7$ & $17.4 \pm 2.1$ \\
\hline Lub-4715 & $3.01 \pm 0.29$ & $60 \pm 4$ & $20.0 \pm 2.4$ & $63.0 \pm 5.2$ & $20.9 \pm 2.7$ \\
\hline Lub-4716 & $3.07 \pm 0.29$ & $58 \pm 3$ & $19.0 \pm 2.1$ & $62.0 \pm 4.1$ & $20.2 \pm 2.4$ \\
\hline Lub-4717 & $3.00 \pm 0.29$ & $61 \pm 4$ & $20.0 \pm 2.4$ & $66.3 \pm 3.9$ & $22.1 \pm 2.4$ \\
\hline Lub-4718 & $3.08 \pm 0.30$ & $64 \pm 3$ & $21.0 \pm 2.3$ & $71.1 \pm 5.1$ & $23.1 \pm 2.8$ \\
\hline Lub-4719 & $3.20 \pm 0.31$ & $144 \pm 10$ & $45.0 \pm 5.4$ & $156 \pm 13$ & $48.6 \pm 6.3$ \\
\hline Lub-4720 & $3.12 \pm 0.31$ & $160 \pm 12$ & $51.0 \pm 6.0$ & $173 \pm 12$ & $55.3 \pm 6.6$ \\
\hline Lub-4721 & $2.97 \pm 0.29$ & $282 \pm 25$ & $95 \pm 12$ & $301 \pm 24$ & $101 \pm 13$ \\
\hline Lub-4722 & $3.17 \pm 0.31$ & $396 \pm 33$ & $125 \pm 16$ & $428 \pm 26$ & $135 \pm 16$ \\
\hline Lub-4723 & $3.01 \pm 0.21$ & $394 \pm 57$ & $131 \pm 21$ & $437 \pm 48$ & $145 \pm 19$ \\
\hline Lub-4729 & $3.10 \pm 0.30$ & $530 \pm 100$ & $171 \pm 38$ & $568 \pm 79$ & $183 \pm 31$ \\
\hline Lub-4728 & $2.93 \pm 0.21$ & $550 \pm 130$ & $187 \pm 45$ & $593 \pm 98$ & $202 \pm 36$ \\
\hline Lub-4727 & $2.88 \pm 0.28$ & $650 \pm 110$ & $227 \pm 43$ & $733 \pm 125$ & $254 \pm 51$ \\
\hline Lub-4726 & $3.02 \pm 0.21$ & $700 \pm 120$ & $231 \pm 43$ & $761 \pm 109$ & $252 \pm 40$ \\
\hline Lub-4725 & $3.03 \pm 0.29$ & $710 \pm 100$ & $235 \pm 40$ & $765 \pm 138$ & $253 \pm 51$ \\
\hline Lub-4724 & $2.99 \pm 0.29$ & $760 \pm 120$ & $254 \pm 46$ & $801 \pm 165$ & $268 \pm 62$ \\
\hline
\end{tabular}

tween 24 and 70 hours in order to minimise the measurement uncertainty.

The concentrations of radioisotopes in $\mathrm{Bq} / \mathrm{kg}$ are converted into absorbed dose rates for $\alpha, \beta$ and $\gamma$ radiation, based on the data published by Adamiec and Aitken (1998). $D_{c}$ was calculated on the basis of data published by Prescott and Hutton (1994). Correction for deposit moisture was calculated after Berger (1988). Discussion on uncertainties of dose-rate calculations was based on the data published by Oczkowski et al. (2000).

\section{RESULTS OF TL DATING OF LOESS DEPOS- ITS FROM BELGIUM AND FRANCE}

To discuss the results of thermoluminescence dating of loess samples from the Boyanychi profile we have to present the results of luminescence dating obtained for 
loess deposited during the last two glaciations in Western and Central Europe. The time-frame of this period, used in our study, was based on mentioned papers below. The duration of MIS 7, correlated with the penultimate interglacial complex, was determined at 244-189 ka by Martinson et al. (1987) and at 245-186 ka by Roucoux et al. (2008). MIS 6 was determined by Martinson et al. (1987) at 189-130 ka. Time brackets corresponding to isotope stages from MIS 5 to MIS 1, compared with the periods of loess deposition, were presented for Western Europe, among others, by Boenigk and Frechen (2001), Frechen et al. (2001), Koster (2005), Rousseau et al. (2002), Thompson and Goldstein (2006) (Fig. 3), and for Poland by Mojski (1999) (Fig. 5).

Many results of luminescence dating of loess deposits from Western and Central Europe are published. Howev-

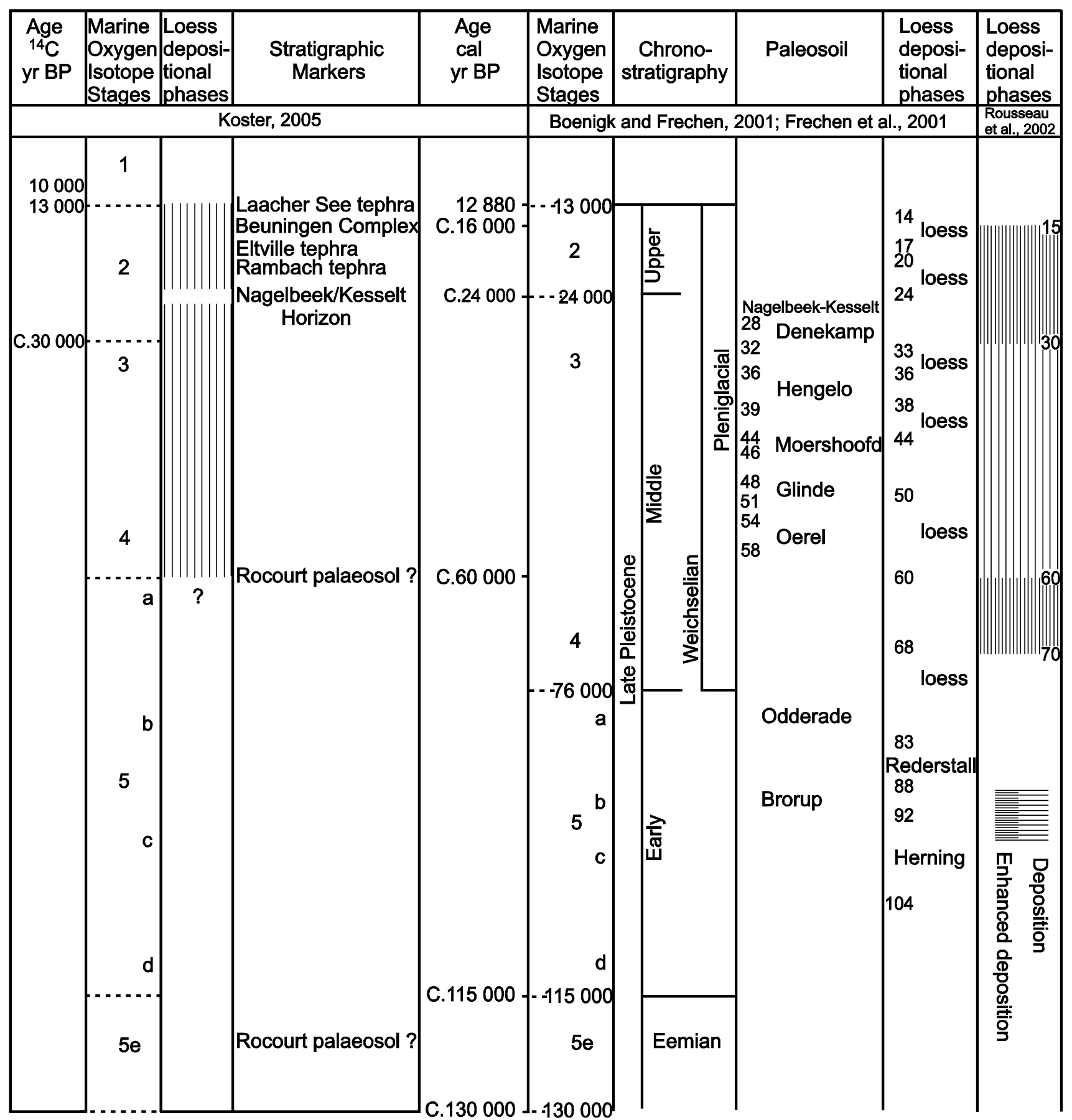

Fig. 3. Chronostratigraphic division of the Upper Pleistocene and periods of loess accumulation in Western Europe according to different authors, compiled by Kusiak (2006). 
er, as the Boyanychi profile is dated using the totalbleach method, the TL dates obtained by the same technique are most notable for us. Therefore, in Fig. 4 we present the TL ages of loess deposits from Achenheim in France, Kesselt, Momalle and Rocourt in Belgium, which were obtained in the Heidelberg, Ghent, Cheltenham and Lublin laboratories (Frechen et al., 2001; Kusiak, 2006; Rousseau et al., 1998; Van den Haute et al., 2003; Zöller et al. 2004). The samples from the Rocourt profile were dated in the Lublin laboratory in 1998, using the optical filter BG-28 after preheating at $160^{\circ} \mathrm{C}$ for 3 hours.

The oldest deposits, which were TL dated in the Achenheim profile are correlated with the antepenultimate glacial (MIS 8), penultimate interglacial (MIS 7) and penultimate glacial (MIS 6 and 5e - deposits forming the Bt horizon), and in the Kesselt, Momalle and Rocourt profiles, are correlated with the penultimate glacial (MIS 7, 6 and 5e. The TL results obtained for the Achenheim profile correspond well to the expected age (Fig. 4). The dates obtained for the others profiles are difficult to interpret because some of them correspond well to the expected age (190 $\pm 36 \mathrm{ka}, 174 \pm 34 \mathrm{ka}, 152.0 \pm 6.2 \mathrm{ka}, 137 \pm 29$ $\mathrm{ka}, 134 \pm 24 \mathrm{ka}, 125.7 \pm 11.5 \mathrm{ka})$, and some are considerably underestimated $(118 \pm 23 \mathrm{ka}, 118 \pm 19 \mathrm{ka}, 102 \pm 21 \mathrm{ka}$, $102 \pm 17 \mathrm{ka}, 97.5 \pm 12.2 \mathrm{ka}, 83.3 \pm 10.4 \mathrm{ka}, 63 \pm 10 \mathrm{ka}$, $54.2 \pm 6.5 \mathrm{ka})$.

Before we try to explain the causes of these anomalies, we should stress that the TL dates corresponding well to the expected age, as well as those underestimated, were obtained for loess deposits from the penultimate glacial occurring in many West European, Polish and Ukrainian sites. For example, TL dates well describing

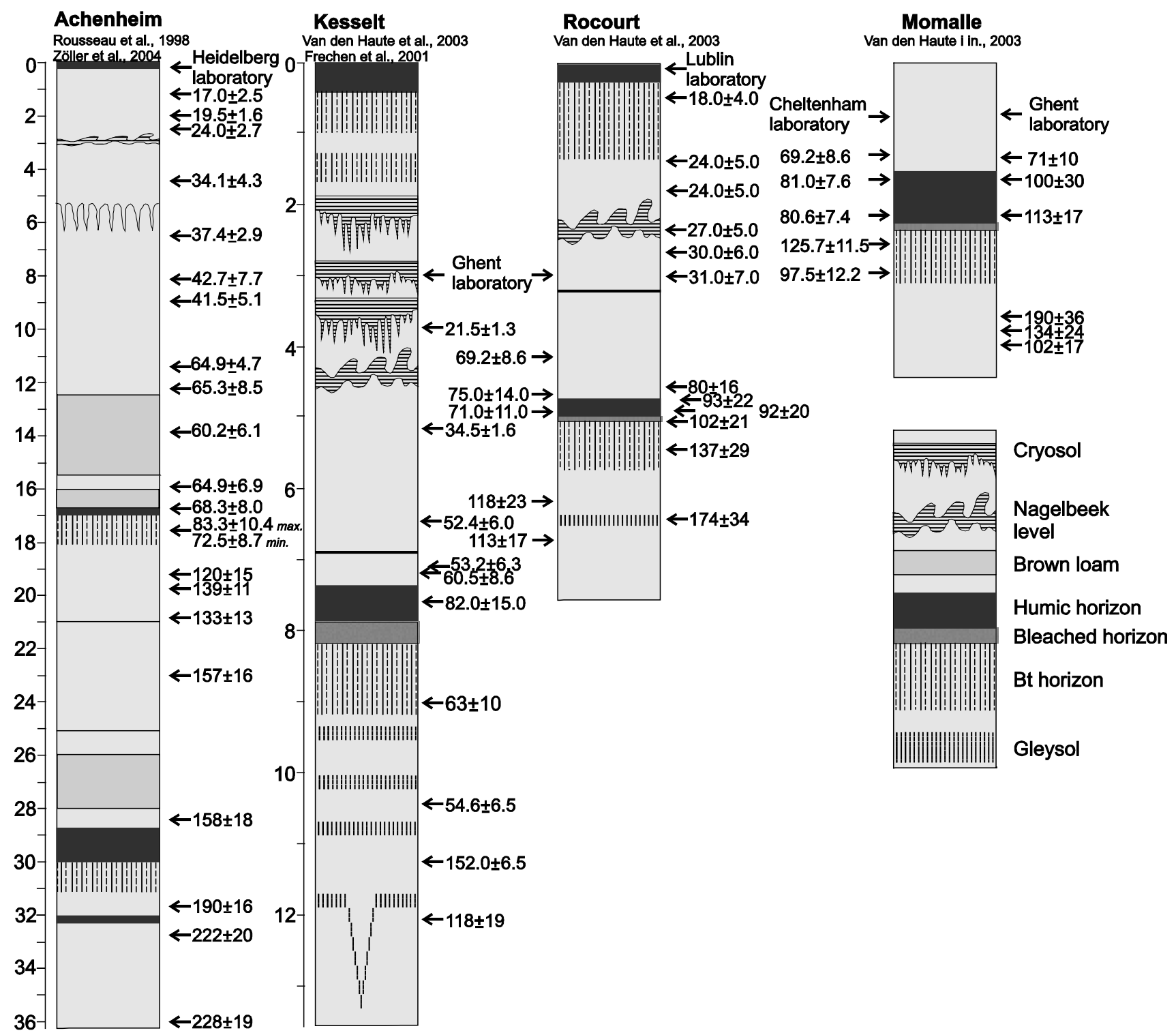

Fig. 4. Correlation of the loess/palaeosol sequences from the sections Kesselt, Momalle and Rocourt in Belgium and Achenheim in France. 
deposit ages were obtained in Germany (Nussloch profile, $162 \pm 15 \mathrm{ka}$, Antonie et al., 2001), Belgium (Harmignies profile, $161.0 \pm 13.5 \mathrm{ka}$, Frechen et al., 2001), SE Poland (seven profiles, $16 \mathrm{TL}$ ages ranging from 187 to $139 \mathrm{ka}$, Kusiak et al., 2007), and Ukraine (Kolodiiv profile, $121 \pm 18 \mathrm{ka}, 146 \pm 22 \mathrm{ka}, 151 \pm 21 \mathrm{ka}$, Kusiak, 2007; Yezupil profile, $143 \pm 20 \mathrm{ka}$, Łanczont et al., 2009). On the other hand, several TL ages obtained in the Lublin laboratory for Ukrainian loesses are considerably underestimated. For example, loess correlated with the penultimate glacial from the Krukenyci IVB profile was TL dated at 55 $\pm 24 \mathrm{ka}$ (Bogucki et al., 2000b). The deposits correlated with the oldest part of the penultimate glacial from the Velykyi Glybochok profile were TL dated at $133 \pm 21 \mathrm{ka}, 145 \pm 17 \mathrm{ka}, 152 \pm 21 \mathrm{ka}$ and $140 \pm 21 \mathrm{ka}$ (Bogucki et al., 2009), and from the Marynopil profile at $125 \pm 31 \mathrm{ka}$ and $137 \pm 39 \mathrm{ka}$ (Lanczont and Bogucki, 2002).

The reasons of this underestimation have not been unambiguously explained till now. It can be supposed that it resulted from the properties of mineral material constituting the dated layers because both "good" and considerably underestimated TL ages were obtained in the same laboratories. The other reason, especially for older deposits, can be extrapolation far beyond the measured points (Mejdahl, 1986). Sometimes, for the same dose there are obtained considerably different values of thermoluminescence intensity in different measurement series. In case of such anomaly the value of equivalent dose obtained by extrapolation of growth curve is accidental, not related to deposition age. In the Lublin laboratory these problems are minimized by repeated (3-5 times) measurement series (32-40 glow curves in each series) and by irradiation of samples with very high doses.

For humus horizon of the Early Vistulian soil (MIS 5 a-d) found in the above presented profiles (Achenheim, Kesselt, Momalle and Rocourt) there were obtained nine TL dates in four laboratories (Fig. 4). The results are considerably scattered. The reasons can be different. It is possible that this long period is represented in individual profiles by soils developed in its different parts, e.g. during the older interstadial (Brorup s.l.) or younger one (Odderade). Loess profiles, in which this period is represented by the complex of 2-3 soils separated by loess layers, are rather rarely found (Behre, 1989; Bińka and Grzybowski, 2001; Emontspohl, 1995; Komar et al., 2009; Paepe and Vanhoorne, 1967 and many other authors). Two of the obtained TL ages $(68.3 \pm 8.0 \mathrm{ka}$ and $71 \pm 11 \mathrm{ka})$ seem to be slightly underestimated, and this fact can be explained by an admixture of younger material due to pedofauna activity. The TL dates obtained in Lublin and Ghent laboratories for the Rocourt profile differ by over 20 percent, similarly as those obtained in Ghent and Cheltenham for the Momalle profile. It probably resulted from purely technical differences in the measurements of radioisotopes concentration and thermo- luminescence as the results obtained in Lublin for the Rocourt profile and in Cheltenham for the Momalle profile are more similar. The same regularities occur for the values of dose rate and equivalent dose obtained in the three mentioned laboratories. The dose rate values obtained for the Momalle profile in Cheltenham are $2.89 \pm 0.26 \mathrm{~Gy} / \mathrm{ka}$ (REM 35) and $2.85 \pm 0.26 \mathrm{~Gy} / \mathrm{ka}$ (REM 36 ), in Ghent $3.58 \pm 0.19 \mathrm{~Gy} / \mathrm{ka}$ (M43) and $3.76 \pm 0.20$ $\mathrm{Gy} / \mathrm{ka}$ (M44), and those obtained for the Rocourt profile - in Ghent 3.78 $\pm 0.19 \mathrm{~Gy} / \mathrm{ka}$ (S35), in Lublin 2.75 \pm 0.25 Gy/ka (Lub-3246) and 2.71 $\pm 0.26 \mathrm{~Gy} / \mathrm{ka}$ (Lub-3247). The $E D$ values obtained for the Momalle profile in Chelten-

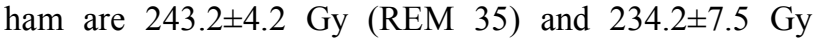
(REM 36), in Ghent 404 \pm 36 Gy (M43) and 374 \pm 135 Gy (M44), and those obtained for the Rocourt profile - in Ghent $269 \pm 17$ Gy (S35), in Lublin 250 \pm 45 Gy (Lub3246) and 255 \pm 54 Gy (Lub-3247) (Kusiak, 2006; Van den Haute et al., 2003). However, from stratigraphic point of view it is essential that most of results indicate the Early Glacial as the formation period of the TL dated humus horizon.

Almost all dates obtained for the deposits correlated with MIS 4 are within the narrow age range (about 70-60 ka), and they correspond well to the expected age. Only two dates from the Rocourt profile $(75 \pm 14 \mathrm{ka}$ and $80 \pm 16 \mathrm{ka}$ ) are considerably overestimated but it seems to be easy to explain. Both samples were taken from the deposit layer occurring directly over the Early Vistulian soil so fresh mineral material could have been mixed during deposition with blown soil material.

Interpleniglacial and Upper Pleniglacial deposits were dated in the Achenheim, Kesselt and Rocourt profiles, in which the Nagelbeek level was found (Frechen et al., 2001; Rousseau et al., 1998). The Nagelbeek soil is interpreted as a tundra gley (gelic gleysol) that underwent cryoturbation (i.e. periglacial load-casting) and deformation during permafrost degradation (Bertran et al., 2003). Based on the results of TL dating, Juvigné and Wintle (1988) determined the age of this level at about $16 \mathrm{ka}$. However, in the opinion published by Rousseau et al. (1998), this level is the boundary between MIS 3 and MIS 2. Loess occurring below this level in the Achenheim profile was TL dated at 43 to $34 \mathrm{ka}$ (four dates obtained in Heidelberg), in the Kesselt profile - at $34.5 \pm 1.6 \mathrm{ka}$ (in Ghent), and in Rocourt profile - at $31 \pm 7 \mathrm{ka}$ and $30 \pm 6 \mathrm{ka}$ (in Lublin). The Nagelbeek soil from the Rocourt profile was dated in Lublin at $27 \pm 5 \mathrm{ka}$. The deposits overlying the Nagelbeek level were dated at $24.0 \pm 2.7 \mathrm{ka}, 19.5 \pm 1.6 \mathrm{ka}$ and $17.0 \pm 2.5 \mathrm{ka}$ (Achenheim), $21.5 \pm 1.3 \mathrm{ka}$ (Kesselt), and $24 \pm 4 \mathrm{ka}, 24 \pm 5 \mathrm{ka}$ and $18 \pm 4 \mathrm{ka}$ (Rocourt). Despite the differences between the measuring techniques used in different laboratories the results obtained for the Interpleniglacial and Upper Pleniglacial are similar and quite well describe ages of the dated deposits. 


\section{RESULTS OF TL AND IRSL DATING OF LOESS DEPOSITS FROM BELGIUM AND GERMANY}

The results of IRSL and TL dating of the deposits correlated with MIS 6 - MIS 2 from Belgium and Germany were published by Boenigk and Frechen (2001), Frechen (1999), Frechen et al. (2001). The comparison of these results permits us to notice some regularities. The IRSL dates obtained for loess deposits correlated with MIS 6 (189-130 ka; Fig. 5) from Germany range from 103 to $80 \mathrm{ka}$, and even to $60 \mathrm{ka}$. The TL dates are higher (about $140-110 \mathrm{ka}$ ) though the results about 100-80 ka were also obtained. Therefore, the IRSL dates are considerably underestimated. The TL results partially correspond to the expected age but most of them are also underestimated. The illuvial horizon of the soil from the last interglacial from Germany was IRSL dated at 117-92 ka, and TL dated at 130-103 ka. As the TL dates of this horizon should correspond to the age of the deposits from the penultimate glacial, the presented results are generally underestimated.

The expected age of the deposits correlated with MIS 5d-a is $115-76$ ka (Fig. 3, Fig. 5). Loess deposits corre- lated with the substage $5 \mathrm{~d}$ in the Tönchesberg and Koblenz-Metternich profiles (Germany) were IRSL dated at 92-77 ka and TL dated at 116-92 ka. The considerably higher TL dates better correspond to the expected age $(>100 \mathrm{ka})$. On the other hand, the TL and IRSL dating results obtained for the Harmignies profile in Belgium are similar. Loess deposits correlated with the substages $5 \mathrm{~d}-\mathrm{a}$ correspond to two distinct coolings. The lower layer was dated at $125.0 \pm 11.9 \mathrm{ka}, 102.7 \pm 8.9 \mathrm{ka}$ (TL) and $110.7 \pm 12.8 \mathrm{ka}, 110.1 \pm 17.6 \mathrm{ka}$ (IRSL), and the upper one - at $67.7 \pm 5.8 \mathrm{ka}, 99.8 \pm 8.3 \mathrm{ka}, 87.6 \pm 7.6 \mathrm{ka}, 102.7 \pm 9.4 \mathrm{ka}$, $83.9 \pm 7.6 \mathrm{ka}(\mathrm{TL})$ and $64.5 \pm 8.9 \mathrm{ka}, 105.2 \pm 10.1 \mathrm{ka}$, $101.7 \pm 14.4 \mathrm{ka}, 99 \pm 15 \mathrm{ka}, 85.2 \pm 16.8 \mathrm{ka}$ (IRSL).

In the Belgium and Germany profiles the deposits correlated with the Lower Pleniglacial (MIS 4) usually occur as thin layers and are rarely dated. Loess from the Tönchesberg profile (Germany) was TL dated at 78-70 ka, and IRSL dated at about $64 \mathrm{ka}$. The latter value corresponds well to the expected age, and the TL results are partially overestimated. Unusual dating results were obtained for the Harmignies profile - the IRSL dates $(89.4 \pm 11.1 \mathrm{ka}$ and $96.4 \pm 14.0 \mathrm{ka})$ are older than the TL ones $(66.3 \pm 5.9 \mathrm{ka}$ and $61.7 \pm 5.4 \mathrm{ka})$ so only the TL results correspond well to the expected age.

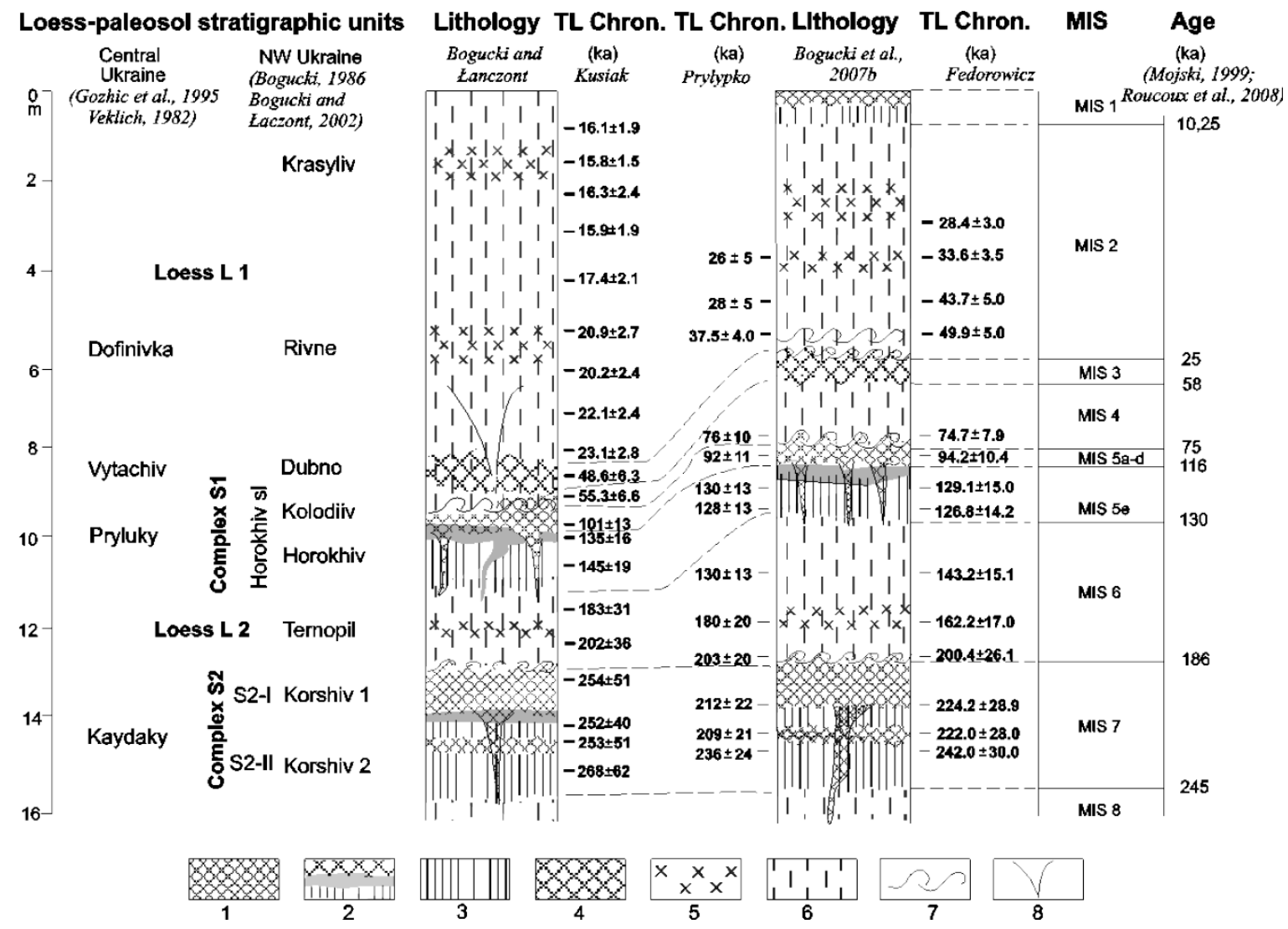

Fig. 5. Stratigraphic setting in relation to the Quaternary stratigraphic schemes in Ukraine (according to Bogucki (1986), Boguckyj and Łanczont (2002), Gozhik et al. (1995), Veklich (1982)), thermoluminescence age of the loess-paleosol sequence in the new Boyanychi (Bojanice) profile by Kusiak (left column), and old ages after Fedorowicz and Prylypko (right column) (Fedorowicz et al., 2008). Boundaries of marine isotope stages after Mojski (1999) and Roucoux et al. (2008). 1 - humus horizon, 2 - eluvial horizon of interglacial soil, 3 - illuvial horizon of interglacial soil, 4 - interstadial soil, 5 - gley signs, initial soil, 6 - loess, 7 - solifluction deformations, 8 - cryogenic wedges. 
According to the stratigraphic scheme developed for Western Europe, several (up to five) warm periods occurred during the Interpleniglacial. However, only the deposits from the older part of this period were found in the Harmignies profile (Belgium). They were TL dated at $59.9 \pm 5.8 \mathrm{ka}, 65.1 \pm 5.7 \mathrm{ka}, 53.2 \pm 5.2 \mathrm{ka}, 50.8 \pm 4.3$, and IRSL dated at $67.7 \pm 7.7 \mathrm{ka}, 68.4 \pm 9.9 \mathrm{ka}, 57.1 \pm 13.8 \mathrm{ka}$, $53.4 \pm 10.4 \mathrm{ka}$. Younger loess deposits occur in the Böckingen profile (Germany), for which the following dates were obtained: $51.4 \pm 4.4 \mathrm{ka}, 38.1 \pm 3.2 \mathrm{ka}, 37.4 \pm 4 \mathrm{ka}$ (TL), and $50.8 \pm 20.5 \mathrm{ka}, 43.5 \pm 6.0 \mathrm{ka}, 27.7 \pm 3.7 \mathrm{ka}$ (IRSL). Almost all presented dates, both TL and IRSL ones, range from 60 to $35 \mathrm{ka}$ so they fall into MIS 3 period. According to a general tendency, the IRSL dates $(57-35 \mathrm{ka})$ are lower than the TL dates (60-41 ka).

Brown soils, occurring in several profiles in southern Germany (e.g. Böckingen and Bönnigheim) and related to the Denekamp and Hengelo interstadials, are also correlated with MIS 3. Many IRSL and TL dating results obtained for these soils are published (Frechen, 1999). Most of the IRSL dates range from 31 to $22 \mathrm{ka}$, and, for the same samples, the TL dates are from 38 to $34 \mathrm{ka}$. The geological age accepted for this period is $39-28 \mathrm{ka}$ (Boenigk and Frechen, 2001). Thus, the TL dates better describe the age of dated deposits, and the IRSL dates are considerably underestimated.

The comparison of the TL and IRSL dating results obtained for the deposits from the Upper Pleniglacial (MIS 2) occurring in southern Germany (Frechen, 1999; Boenigk and Frechen, 2001) indicates that only the IRSL dates describe well the age of the dated deposits as most of them do not exceed $20 \mathrm{ka}$. The TL dates are considerably older (40-20 ka) so they are overestimated. However, not all TL results obtained for the Upper Pleniglacial profiles are such different from the expected age. The Tönchesberg and Koblenz-Metternich profiles were TL dated at 26-23 and 18-15 ka and IRSL dated at 19-17 ka. If we accept that the lower limit of MIS 2 was $24 \mathrm{ka}$, and periods of loess accumulation in the Upper Pleniglacial were 24-20 and 17-14 ka (Fig. 3), we find that only some TL dates are slightly overestimated. Thompson and Goldstein (2006) believe that the lower limit of MIS2 should be set a bit earlier. At this interpretation these TL ages correspond well to the expected age.

The results of OSL and TL dating of the deposits correlated with MIS 6 - MIS 2 from Nussloch (Germany) loesspalaeosol sequences were published by Antoine et al. (2001) and Lang et al. (2003). The OSL dates obtained for loess deposits correlated with MIS $6(61.3 \pm 9.9 \mathrm{ka}$ and $122.0 \pm 17.8 \mathrm{ka})$ are generally underestimated. In the Nussloch profile loess correlated with the Lower Pleniglacial (MIS 4) was TL dated at 66.9 $\pm 5.1 \mathrm{ka}$ and OSL dated at $55.7 \pm 12.6 \mathrm{ka}$ so both results correspond well to the expected age. The comparison of the OSL and ${ }^{14} \mathrm{C}$ dating results obtained for the deposits from the Middle Pleniglacial (MIS 3) and Upper Pleniglacial (MIS 2) indicate that the OSL dates describe well the age of the dated deposits.
Ten ${ }^{14} \mathrm{C}$ ages (at $47-29 \mathrm{ka}$ cal BP) and four OSL dates (at 31-29.5 ka) were obtained for the deposits correlated with Middle Pleniglacial. Fourteen ${ }^{14} \mathrm{C}$ ages (at 27-18 ka cal BP) and thirteen OSL dates (at 26-18 ka) were obtained for the deposits correlated with MIS2.

Based on the above-discussed results, we can find that besides its advantages the OSL and IRSL methods have also limitations. These dates obtained for older deposits are usually underestimated. For this reason we are justified in using the thermoluminescence method for chronostratigraphic investigations of loesses.

\section{THE RESULTS OF THERMOLUMINESCENCE DATING IN THE BOYANYCHI PROFILE}

The samples collected in 2008 were TL dated in 2009. Fourteen TL ages were obtained for the "new" wall and six for the "old" part of the excavation: loess L1 from the last glacial - 11 samples, pedocomplex $\mathrm{S} 1-3$ samples, loess L2 from the penultimate glacial - 2 samples, pedocomplex S2 - 4 samples (Fig. 5, Table 3).

The following results were obtained from top to bottom. The sample from a depth of $0.5 \mathrm{~m}$, i.e. from the loess overlying the Krasyliv horizon, was dated at $16.1 \pm 1.9 \mathrm{ka}$. The Krasyliv horizon was dated at $15.8 \pm 1.5 \mathrm{ka}$. Three TL dates $(16.3 \pm 2.4 \mathrm{ka}, 15.9 \pm 1.9 \mathrm{ka}$ and $17.4 \pm 2.1 \mathrm{ka})$ were obtained for the loess occurring at a depth of 2.1-4.8 $\mathrm{m}$. The Rivne soil horizon was dated at $20.9 \pm 2.7 \mathrm{ka}$. The next thick loess layer $(5.8-8.1 \mathrm{~m})$ was dated at $20.2 \pm 2.4 \mathrm{ka}$, $22.1 \pm 2.4 \mathrm{ka}$ and $23.1 \pm 2.8 \mathrm{ka}$. Directly below the Rivne found shells of snails. They were dated at 19-18 ka cal BP. The age of the Dubno interstadial soil horizon was determined at $48.6 \pm 6.3 \mathrm{ka}$, and of the underlying silty-clayey loess at $55.3 \pm 6.6 \mathrm{ka}$. Three TL ages were obtained for the Horokhiv pedocomplex (S1): A horizon $-101 \pm 13 \mathrm{ka}$, Eet

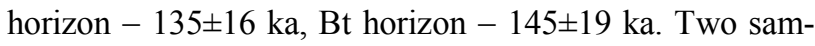
ples of the loess L2 were dated at $183 \pm 31$ ka (loess overlying the Ternopil soil) and $202 \pm 36 \mathrm{ka}$ (loess underlying the Ternopil soil). The Korshiv pedocomplex (S2) yielded the following TL ages: A horizon of the S2-I soil $-254 \pm 51 \mathrm{ka}$, Bt horizon of the S2-I soil $-252 \pm 40 \mathrm{ka}$, A horizon of the S2-II soil $-253 \pm 51 \mathrm{ka}, \mathrm{B}$ horizon of the S2-II soil $268 \pm 62 \mathrm{ka}$.

\section{DISCUSSION}

With reference to the stratigraphic scheme of loesses and paleosols in the NW Ukraine after Bogucki (1986) and Bogucki and Lanczont (2002), the particular parts of the Boyanychi profile can be correlated with the marine oxygen-isotope stages (MIS). The upper part, with the Krasyliv and Rivne horizons, is correlated with MIS 2. The Dubno soil horizon represents an older part of MIS 3, and the underlying loess MIS 4. The Horokhiv pedocomplex is correlated with MIS 5. The upper chernozem layer represents the younger part of MIS 5, i.e. the early Vistu- 
lian. The lower part of the pedocomplex (typical forest soil from the Eemian interglacial) corresponds to substage 5e. This soil developed on loess deposits from the penultimate glacial (MIS 6) with the Ternopil interstadial soil, which was well examined in loess profiles of the Volyn and Podillya regions. The underlying Korshiv pedocomplex is correlated with MIS 7 (Bogucki et al., 2000a, 2007b).

The TL dating results obtained by Kusiak for loesses and paleosols sampled in the Boyanychi profile in 2008 generally correspond well to the stratigraphic division presented by Bogucki (1986) and Bogucki and Łanczont (2002). TL ages of the deposits correlated with MIS 2 range from 15.9 to $23.1 \mathrm{ka}$. A significant age difference of about $4 \mathrm{ka}$ is found between the Krasyliv and Rivne soils, which were dated at $15.8 \pm 1.5 \mathrm{ka}$ and $20.9 \pm 2.7 \mathrm{ka}$, respectively. A similar difference is between the TL ages obtained for the loesses on which these soils developed.

The Krasyliv horizon was TL dated at $28.4 \pm 3.0 \mathrm{ka}$ by Fedorowicz in 2007, 22 \pm 3 ka by Butrym in 1992, and $35 \pm 4$ ka by Szelkoplyas in 1985 (Fig. 5; Lindner and Marks, 2008). However, the result obtained by Szelkoplyas is dubious because he obtained identical results for four samples from the depth of 0-6 m.

No other TL dates are found in literature for the Krasyliv horizon. This buried active layer of permafrost is poorly examined because it has been obliterated by Holocene pedogenesis or destroyed by denudation at the close of the glacial due to its occurrence in the near-surface part of the Upper Plenivistulian loess. In the Volyn and Podillya regions the greatest casts of ice wedges reaching to a depth of $6 \mathrm{~m}$ are connected with the Krasyliv horizon. In the Halych Prydnistrov'ja region the Krasyliv horizon contains artefacts. Based on them, it is recognized as the Late Palaeolithic layer from the last part of the Plenivistulian (Nawrocki et al., 2003; Bogucki and Łanczont, 2002). The pollen-spore assemblage of the Krasyliv horizon represents glacial vegetation. The deposits were accumulated during the development of vegetation cover with many features similar to those of the Late Pleistocene flora. The next changes of climatic conditions, i.e. warming, resulted in the expansion of forests, and gradual disappearance of tundra elements and steppe vegetation of xerothermic type (Bezuśko and Bogucki, 1993).

The Rivne horizon in the Boyanychi profile was TL dated by Fedorowicz at $26 \pm 5 \mathrm{ka}$ and by Prylypko at $33.6 \pm 3.5 \mathrm{ka}$. Such a great difference can indicate that mineral material was heterogeneous and underwent a short transport, thus these results are not reliable. This speculation is confirmed by fact that Kusiak obtained the considerably younger TL age ( $20.9 \pm 2.7 \mathrm{ka})$ for the Rivne horizon sampled in the new wall in 2008. The Rivne horizon was also dated in the Halych profile by Fedorowicz (20.0-21.9 ka) and Kusiak (17.7-20.1 ka) (Lanczont and Madeyska, 2005). Therefore, similar results were obtained in two laboratories for this horizon sampled at two sites.

Several other data concerning the age of the Rivne soil horizon are also available. Artefacts found in many archaeological sites of the Halych Prydnistrov'ja region, occurring in a one-horizon soil corresponding to the Rivne unit or directly below it, are placed into the second half of the Upper Palaeolithic and correlated with the Lascaux interphase distinguished within the Upper Plenivistulian. Organic deposits from the equivalent Mazurian interphase in Poland were dated conventional ${ }^{14} \mathrm{C}$ at $17.8 \mathrm{ka}$ BP (Mojski, 1968, 1993; Lindner, 1991). Many dating results of organic and mineral material as well as bone remains from the Rivne soil and adjacent layers, obtained using different methods, fall within a rather large range. Radiocarbon conventional ages of charcoals and bones from the Halych profile range from 19.6 to $23.2 \mathrm{ka}$ BP. Bone remains in the Mezhygircy were radiocarbon conventional dated at 17.2-20.3 ka BP. Bone remains from these sites were also dated using the U-Th method. The obtained results range from $10 \mathrm{ka}$ to $25 \mathrm{ka}$. The authors stress that the analysed material was difficult to date irrespective of the method used (Bogucki and Łanczont, 2002; Nawrocki et al., 2003; Łanczont and Madeyska, 2005).

The loess underlying the Rivne horizon was dated by Fedorowicz $(43.7 \pm 5.0 \mathrm{ka}$ and $49.9 \pm 5.0 \mathrm{ka})$, Prylypko $(28 \pm 5 \mathrm{ka}$ and $37.5 \pm 4.0 \mathrm{ka}$ ) and Kusiak (from $20.2 \pm 2.4 \mathrm{ka}$ to $23.1 \pm 2.8 \mathrm{ka}$ ). The very large discrepancy of the results obtained in three laboratories presents great interpretative problems.

The Dubno soil is a key horizon in the Vistulian loesses of the Volyn and Podillya regions. This soil is mostly developed as homogeneous gley soil deformed by huge involutions. Until recently it was generally related to the Interplenivistulian or its younger part (e.g. Maruszczak, 1994; Jary, 2007). However, the investigations carried out in the Prydnistrov'ja region revealed that this period is represented by at least two soils (Dubno 1 correlated with substage 3.1 and Dubno 2 with substage 3.3), which are superimposed or separated by loess layers (Eanczont and Bogucki, 2007). It appears that the Dubno unit found in many loess profiles was formed by accumulation, pedogenesis and denudation processes, which occurred during MIS3 or at the beginning of MIS2. The Dubno horizon in the Boyanychi profile was TL dated by

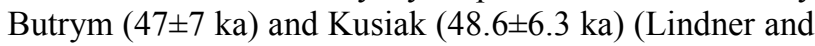
Marks, 2008; Fig. 5). Based on these similar results, we can correlate this soil with the Dubno 2 stratigraphic unit.

The loess underlying the Dubno 2 soil in the Boyanychi profile was TL dated by Fedorowicz (74.0 \pm 7.9 ka), Prylypko ( $76 \pm 10 \mathrm{ka})$ and Kusiak (55.3 $\pm 6.6 \mathrm{ka})$. If we accept (after Mojski, 1999) the time limits of the Lower Plenivistulian $(58-75 \mathrm{ka})$, we find that the results obtained by Fedorowicz and Prylypko are slightly overestimated, and those by Kusiak are somewhat underestimated. In the "new" wall, sampled in 2008 and dated by 
Kusiak, this loess is very thin and clearly without the lower part. In the exposure examined in 2007 there is much a thicker and probably complete loess unit representing MIS4. Taking into account the situation of sampling places in these two exposures, it is probable that the obtained TL ages represent the beginning and the end of deposition of this loess unit.

While the TL dating results obtained in the years 2007-2009 in the Gdańsk, Kiev and Lublin laboratories for the upper part of the Boyanychi profile were very scattered, those for the lower part are similar. The A horizon of the Horokhiv soil was dated in the Gdańsk, Kiev and Lublin laboratories at $94.2 \pm 10.4 \mathrm{ka}, 92 \pm 11 \mathrm{ka}$ and $101 \pm 13 \mathrm{ka}$, respectively. The Eet horizon was dated only in the Lublin laboratory at $135 \pm 16 \mathrm{ka}$. The results obtained in three laboratories for the Bt horizon range from ca. 127 to ca. $145 \mathrm{ka}$. Some differences between the dates obtained by Kusiak ( $183 \pm 31 \mathrm{ka})$, Fedorowicz $(143.2 \pm 15.1 \mathrm{ka})$ and Prylypko $(130 \pm 13 \mathrm{ka})$ for the loess overlying the Ternopil soil could have resulted from different sampling depths. Kusiak dated the sample taken just above the Ternopil soil, while two other samples were collected close to the top of the loess layer. This seems to be confirmed by the TL ages obtained for the Ternopil soil in Gdańsk (162 $\pm 17 \mathrm{ka})$ and Kiev $(180 \pm 20$ $\mathrm{ka})$. The results obtained in three laboratories for the loess underlying the Ternopil soil range from 200 to 203 ka. The TL ages of the horizons of the Korshiv pedocomplex are also very similar. The following results were obtained in Gdańsk, Kiev and Lublin, respectively:

A horizon of the S2-I soil: $224.2 \pm 28.9 \mathrm{ka}, 212 \pm 22 \mathrm{ka}$ and $254 \pm 51 \mathrm{ka}$;

A horizon of the S2-II soil: $222.1 \pm 28.0 \mathrm{ka}, 209 \pm 21 \mathrm{ka}$ and $253 \pm 51 \mathrm{ka}$;

B horizon of the S2-II soil: $242.0 \pm 30.0 \mathrm{ka}, 236 \pm 24 \mathrm{ka}$ and $268 \pm 62 \mathrm{ka}$.

Similar results were also obtained by Butrym in 1992 (Lindner and Marks, 2008). The Ternopil soil was dated at $167 \pm 25 \mathrm{ka}$ and $179 \pm 27 \mathrm{ka}$. The results obtained for the Korshiv pedocomplex were as follows: A horizon of the S2-I soil - $212 \pm 32 \mathrm{ka}$; B horizon of the S2-I soil $212 \pm 32 \mathrm{ka}$; A horizon of the S2-II soil $-238 \pm 35 \mathrm{ka}$; B horizon of the S2-II soil $-243 \pm 36 \mathrm{ka}$.

The results obtained by Szelkoplyas in 1985 are very scattered and their interpretation is very difficult (Lindner and Marks, 2008).

\section{FINAL REMARKS AND CONCLUSIONS}

As was stressed in the introduction, the Boyanychi site is of essential importance for the Quaternary stratigraphy in Central Europe (Lindner and Marks 2008). It is one of the most complete and best examined profiles with almost continuous loess-soil series of the Middle and Upper Pleistocene. It was studied and visited by many Ukrainian and Polish researchers. Its situation near the Polish-Ukrainian border gives also prospects for strati- graphic correlation of the Polish and Ukrainian schemes of the Pleistocene. The Boyanychi profile has aroused interest of specialists dealing with thermoluminescence dating. Fedorowicz et al. (2008) presented the TL dating results obtained for the Boyanychi profile in different laboratories during the last 23 years, i.e. in Kiev in 1985, in Lublin in 1992, and in Gdańsk and Kiev in 2007 (results of parallel dating). In this paper we discussed the results published by Fedorowicz et al. (2008) and those obtained in the Lublin laboratory in 2009.

The TL ages obtained in three laboratories by Fedorowicz, Prylypko and Kusiak can be divided into two parts. The first group contains the consistent results obtained for the Horokhiv and Korshiv pedocomplexes and loess from the penultimate glacial separating them. These results confirm unambiguously the stratigraphic interpretation of the profile published by Bogucki et al. (1995, 2007b). It should be stressed that the loess from the penultimate glacial and the Korshiv pedocomlex were sampled in the same part of the excavation for TL dating in all laboratories, though not at the same time and in the exactly same places. In chapter 4 we presented the examples of underestimated TL dating results obtained for loess deposits from the penultimate glacial. This problem did not appear for the Boyanychi profile. The deposits correlated with MIS 7 were dated in three laboratories and the obtained results were consistent. Such consistence is very rare when dating such old deposits. However, the reasons of this consistence are not possible to discuss because Fedorowicz et al. (2008) did not publish the values of dose rates and equivalent doses obtained in the Gdańsk and Kiev laboratories.

The results from the second group are very divergent. The upper part of the profile was examined in different, though not distant to each other, parts of the excavation in 2007 and 2008, and the obtained TL ages were very different. Moreover, the results obtained in 2007 in the Kiev and Gdańsk laboratories were also incompatible. The different results for the Krasyliv and Rivne soil horizons and the underlying loesses lead to different stratigraphic interpretations of the upper part of the profile. Based on the TL ages obtained by Fedorowicz and Prylypko in 2007, this part of the profile should be correlated with MIS3, and based on the TL ages obtained by Kusiak in 2009 with MIS2. The second interpretation better corresponds to the stratigraphic schemes of loesses in the Volyn (Bogucki, 1986) and in the Halych Prydnistrov'ja region (Bogucki and Łanczont, 2002) and to the palaeogeographic situation.

It is difficult to discuss the causes of the differences between the results obtained in 2007 and 2009. However, the regularly higher values of TL ages obtained in 2007 probably indicate that the deposits in the wall exposed in 2007 contain mineral material not completely zeroed before deposition. It cannot be excluded that aeolian deposition was supplemented with an admixture of material derived from local deflation of older deposits. In 
consequence the TL ages of the Rivne and Krasyliv horizons, developed on these "aged" deposits, are incompatible with their stratigraphic positions. On the other hand, in the part of the loess cover examined in 2008 the accumulation exhibited considerably greater thickness of the distinguished layers of the Upper Plenivistulian loess, and it was probably fresh dust. The greater thickness was probably caused by participation of hillwash processes as evidenced by stratification indicating that the depositional surface was inclined eastwards (at a $10^{\circ}$ angle). Such synsedimentary supply of fresh material did not change thermoluminescence features of the accumulated deposit. Such deposition was conditioned by cold and dry climate as indicated not only by the features of sedimentation structures but also by the reconstructed ecological conditions. Halophytes and cold-loving species predominated in vegetation cover, and typical loess assemblage of mollusks contained up to $80-90 \%$ of Pupilla loessica and Pupilla muscorum (Bogucki and Bezusko, 1993; Dmitruk, 2001). Typical solifluction structures are absent in this loess. In the examined profile they occur in the layers correlated with the lower part of MIS 2 (directly above the Dubno horizon).

It should be stressed that the results of TL dating obtained in the Lublin laboratory for the upper part of the Boyanychi profile correspond well to the time intervals determined as periods of loess deposition and formation of paleosols in Western Europe (cf. Fig. 3). The date $55.3 \pm 6.6$ ka obtained for loess underlying the Dubno soil corresponds well to the period of loess deposition from 60 to $50 \mathrm{ka}$. A sample from the Dubno soil was TL dated at $48.6 \pm 6.3 \mathrm{ka}$, and this result falls into the time interval 51-48-44 ka determined for the Glinde interstadial. The Upper Pleniglacial loess deposits in the Boyanychi profile were accumulated from 23 to $20 \mathrm{ka}$ and from 17 to 16 $\mathrm{ka}$, i.e. in the time intervals corresponding to the periods of loess deposition (24-20 ka and 17-14 ka) distinguished for Western Europe (Boenigk and Frechen, 2001; Frechen et al., 2001).

A case study from the Boyanychi site with typical upland loesses is an excellent example confirming the fact that local palaeorelief differences, almost in microrelief scale, had a great influence on the final features and thickness of the deposited loess. It is also obvious that these conditions changed with time. After each stage of accumulation and fixation of surface by vegetation, the next stage of deposition and local differences in its intensity resulted in obliteration of old microrelief forms and formation of new ones. Relief forms were also influenced by erosion and denudation, which were more intensive at the turn of warm and cold periods. Therefore, the results of study in the Boyanychi site provided us once again with the arguments confirming an important role of short mass transport and local variability of loess accumulation conditions in different stages of their formation, which could result in incomplete luminescence zeroing of transported mineral material.
The results of many years' investigations in the Boyanychi site confirm us in our belief that loess profiles should be densely sampled for TL dating, and the obtained results should be verified by interlaboratory comparisons.

\section{ACKNOWLEDGEMENT}

We would like to express our gratitude to Dr. Maria Wilgat who prepared the English version of this paper, and to Mgr. Ewa Sadowska for the graphic preparation of the figures.

\section{REFERENCES}

Adamiec G and Aitken MJ, 1998. Dose-rate conversion factors: update. Ancient TL 16: 37-50.

Antoine P, Rousseau DD, Zöller L, Lang A, Munaut AV, Hatte C and Fontugne M, 2001.High-resolution record of the last Interglacialglacial cycle in the Nussloch loess-palaeosol sequences, Upper Rhine Area, Germany. Quaternary International 76-77: 211-229, DOI 10.1016/S1040-6182(00)00104-X.

Balescu S, Packman SC and Wintle AG, 1991. Chronological separation of interglacial raised beaches from Northwestern Europe using thermoluminescence. Quaternary Research 35(1): 91-102, DOI 10.1016/0033-5894(91)90097-O.

Berger GW, 1988. Dating Quaternary events by luminescence. Geological Society of America, Special Paper 227: 13-50.

Berger GW, Pillans BJ and Palmer AS, 1992. Dating loess up to $800 \mathrm{ka}$ by thermoluminescence. Geology 20(5): 403-406, DOI 10.1130/0091-7613(1992)020<0403:DLUTKB>2.3.CO;2.

Behre KE, 1989. Biostratigraphy of the last glacial period in Europe. Quaternary Science Reviews 8(1): 25-44, DOI 10.1016/02773791(89)90019-X.

Bertran P, Fontugne M and Jaubert J, 2003. Permafrost aggradation followed by brutal degradation during the Upper Pleniglacial in Mongolia: the probable response to the H2 Heinrich event at 21 kyr BP. Permafrost and Periglacial Processes 14: 435-443.

Bezuśko LG and Boguckij AB, 1993. Warunki paleogeograficzne formowania się lessów i gleb kopalnych górnego plejstocenu w południowo-zachodniej części Platformy Wschodnioeuropejskiej (Paleogeographic conditions of loess and fossil soil formation of the Upper Pleistocene in the southwest part of the East-European Platform). Annales UMCS sec. B 48(2): 19-24 (in Polish).

Bińka K and Grzybowski K, 2001. Early Vistulian Deposits at Świnna Poręba, Western Outer Carpathians (S Poland). Studia Quaternaria 18: 11-16.

Bluszcz A, 1987. Sprawozdanie z datowania termoluminescencyjnego próbek lessu z Odonowa. (Report on thermoluminescence dating of loess samples from Odonów). Sprawozdania z badań naukowych KBN 7: 8-9 (in Polish).

Boenigh W and Frechen M, 2001. The loess record in sections at Koblenz-Metternich and Tönchesberg in the Middle Rhine Area. Quaternary International 76-77: 201-209, DOI 10.1016/S10406182(00)00103-8.

Bogucki (Boguckyj) AB, 1986. Antropogenovye pokrovnye otloženija Volyno-Podolji (Anthropogenic cover deposits of the VolynPodillya). In: Antropogenovye otloženija Ukrainy, Naukova Dumka, Kiev: 121-132 (in Ukrainian).

Bogucki AB and Bezusko L, 1993. Paleogeographic conditions of Loess and Fossil Soil Formation of the Upper Pleistocene in the Southwest Part of the East-European Platform. Annales UMCS sec. B 48: 19-24.

Bogucki (Boguckyj) AB and Łanczont M, 2002. Stratygrafia lessów Naddniestrza Halickiego (Loess stratigraphy in the Halyč Prydnistrov'ja region). In: Madeyska T, ed., Lessy i paleolit Naddniestrza halickiego (Ukraina) (Loess and Palaeolithic of the Dniester River 
Basin, Halyč region (Ukraine)). Studia Geologica Polonica 119: 315-327 (in Polish).

Bogucki (Boguckij) AB, Wieliczko AA, Gerenczuk KI, Gruzman GB, Demediuk NS, Zalesskij II, Krawczuk JS, Morozowa TD, Neczajew WP, Palienko WP, Cackin AI and Czugunnyj JG, 1980. Opornyje razrezyi krajewyje obrazowanija materikowych oledenenii zapadnij czasti Ukrainy (Outcrops and marginal glacial formations in western Ukraine). Institut Geologicheskich Nauk AN USSR Preprint 80-17: 1-51 (in Ukrainian).

Bogucki AB, Bogucki A and Wołoszyn P, 1994. Reperowy profil Bojanice i niektóre problemy badawcze lessowo-glebowych serii peryglacjalnych plejstocenu (Stratotype section Bojanice and some research problem of loess-palaeosol periglacial series of the Pleistocene). In: Wilgat T, ed., Przewodnik wycieczkowy Ogólnopolskiego Zjazdu Polskiego Towarzystwa Geograficznego. Towarzystwo Wolnej Wszechnicy Polskiej, Oddział w Lublinie: 246-249 (in Polish).

Bogucki AB, Maruszczak H and Nawrocki J, 1995. Stratigraphic and Paleogeographic Interpretation of Analysis Results of Magnetic Susceptibility of Loesses in Bojanice (NW Ukraine). Annales UMCS 50, sec. B: 51-64.

Bogucki (Bogutsky) AB, Łanczont M and Wojtanowicz J, 2000a. The Korshov (=Lublinian) interglacial and oxygene isotope stage 7 in the loess profiles of Poland and Ukraine. Ukraina ta globalni procesi, geografičnii simir. Kiev-Luck 2: 185-186.

Bogucki A, Łanczont M and Wojtanowicz J, 2000b. Nowe profile czwartorzędu w rejonie Krukienic - ich znaczenie stratygraficzne i paleogeograficzne (New Quaternary profiles near Krukienice their stratigraphic and palaeogeographic significance). Seminarium terenowe „Glacjat i peryglacjat na międzyrzeczu Sanu i Dniestru” Krasiczyn, 4-6.10.2000: 112-125 (in Polish).

Bogucki (Boguckij) AB, Łanczont M and Wojtanowicz J, 2004. Zagadnienia glacjalne i peryglacjalne na międzyrzeczu Sanu i Dniestru w świetle nowych badań profilu Dubaniewice (Ukraina) (Glacial and periglacial problems of the San and Dniestr interfluve in the light of new investigations of the Dubanevyči profile (Ukraine)). Annales UMCS sec. B 59(2): 45-60 (in Polish)

Bogucki (Boguckij) AB, Hołub B and Łanczont M, 2007a. Wolyn'ska Wysoczyzna: golowni rysy geologicznoj budowy ta reliefu (Main feature of the geological structure and relief of the Volhynia Upland). In: (Bogucki) Boguckyj AB, ed., Problemy serednoplejstocenoho interglacjalu. Centrum Wydawnicze Narodowego Uniwersytetu im. I. Franko: 6-10 (in Ukrainian).

Bogucki AB, Wojtanowicz J, Wołoszyn R, Dmitruk R, Łanczont M and Madeyska T, 2007b. Stratigraficzna pozicja korsziwskowo gruntowogo kompleksa w lessowo-gruntowych rozriezach Wolynskoj wysoczyny (Stratigraphic position of the Korshiv fossil pedocomplex in the loess-soil series of the Volyn Upland). In: Bogucki (Boguckyj) AB, ed., Problemy serednopleistocenowo interglacjała (Problems of the Middle Pleistocene interglacial). Centrum Wydawnicze Narodowego Uniwersytetu im. I. Franko: 11-25 (in Ukrainian).

Bogucki (Boguckyj) A, Łanczont M, Łącka B, Madeyska T and Sytnyk O, 2009. Age and the palaeoenvironment of the West Ukrainian palaeolithic: the case of Velykyi Glybochok multi-cultural site. Journal of Archaeological Science 36(7): 1376-1389, DOI 10.1016/j.jas.2009.01.027

Brumby S, 1992. Regression analysis of ESR/TL dose-response data. Nuclear Tracks and Radiation Measurements 20(4): 595-599, DOI 10.1016/1359-0189(92)90010-S.

Buraczyński J, 1995. Profil lessowy Samborzec na Wyżynie Sandomierskiej (The Pleistocene sediments at Samborzec near Sandomierz). In: Konferencja „Problemy Geomorfologii i Paleogeografii Czwartorzedu, Lublin, 10-11 kwietnia 1995: 21-22 (in Polish).

Butrym J, 1987. Wiek TL lessów z profilu w Odonowie k/ Kazimierzy Wielkiej. (TL age of loesses from the Odonów profile near Kazimierza Wielka). Sprawozdania z badań naukowych KBN 7: 10-15 (in Polish)

Chlebowski R, Lindner L, Barczuk A, Bogucki A, Gozhik P, Łanczont $\mathrm{M}$ and Wojtanowicz J, 2002. Warunki akumulacji lessów młodszych górnych Wyżyny Lubelskiej (Polska) i Wyżyny Wołyńskiej
(Ukraina) na podstawie badań geologicznych i mineralogicznych (The conditions of accumulation of the upper younger loesses in the Lublin Upland (Poland) and Volyn Upland (Ukraine) based on geological and mineralogical research). In: Sołtysik R, ed., II Świętokrzyskie spotkania geologiczno-geomorfologiczne nt. Peryglacjat plejstoceński w osadach i rzeźbie Polski (The 2nd Holly Cross geological-mineralogical meeting entitled "Pleistocene periglacial in deposits and relief of Poland"). Instytut Geografii AS, Instytut Geologii Podstawowej UW: 18-20 (in Polish).

Chlebowski R, Lindner L, Barczuk A, Bogucki (Bogutsky) A, Gozhik $\mathrm{P}$, Łanczont $\mathrm{M}$ and Wojtanowicz J, 2003. Accumulation conditions of the younger upper loesses of Sandomierz Basin, MidCarpathian Foreland and Podolian Upland (border between SE Poland and NW Ukraine) on the basis of the geological and mineralogical studies. Annales UMCS 58, sec. B: 7-63.

Cys' PM, 1962. Geomorfologia URSR (Geomorphology URSR). Wydawnictwo Lvivskoho Uniwersytetu: $221 \mathrm{pp}$ (in Ukrainian).

Dmitruk RJ, 2001. Wierchnopleistocenowa fauna moluskow w profile Bojaniczi II i jej paleogeograficzna interpretacja (Upper Pleistocene molluscs fauna in the Boyanychi profile and them palaeogeographical interpretation. Geografija i suczasnost 5, Widmo, Kijów: 71-79 (in Ukrainian).

Emontspohl AM, 1995. The northwest European vegetation at the beginning of the Weichselian glacial (Brørup and Odderade interstadials) - new data from northern France. Review of Palaeobotany and Palynology 85: 231-242.

Fedorowicz S, 2006. Metodyczne aspekty luminescencyjnego oznaczania wieku osadów neoplejstoceńskich Europy Srodkowej (Methodological aspects of luminescence dating of Central Europe's Neopleistocene deposits). Wydawnictwo Uniwersytetu Gdańskiego: $156 \mathrm{pp}$ (in Polish).

Fedorowicz S, Prylypko S, Bogucki A and Łanczont M, 2008. Międzylaboratoryjne porównanie dat termoluminescencyjnych (TL) próbek z profilu Bojanice (Ukraina) (Interlaboratory comparison of thermoluminescence (TL) ages of samples from the Boyanychi profile (Ukraine)). In: Book of abstracts XV Konferencja „Stratygrafia plejstocenu Polski” Zakopane 1-5 September 2008: 92-95 (in Polish)

Frechen M, 1992. Systematic thermoluminescence dating of two loess profiles from the Middle Rhine Area (F.R.G.). Quaternary Science Reviews 11(1-2): 93-101, DOI 10.1016/0277-3791(92)90048-D.

Frechen M, 1999. Upper Pleistocene loess stratigraphy in Southern Germany. Quaternary Science Reviews 18(2): 243-269, DOI 10.1016/S0277-3791(98)00058-4.

Frechen M, Van Vliet-Lanoë B and Van den Haute P, 2001. The Upper Pleistocene loess re-cord at Harmignies/Belgium - high resolution terrestial archive of climate forcing. Palaeogeography, Palaeoclimatology, Palaeoecology 173(3-4): 175-195, DOI 10.1016/S00310182(01)00319-4.

Gozhik P, Shelkopyas V and Khristoforova T, 1995. Development Stages of Loessial and Glacial Formations in Ukraine (Stratigraphy of Loesses in Ukraine). Annales UMCS, sec. B, 50: 65-74.

Grün R, 1994. Fit-Sim. Computer program, QDRC, Canberra.

Grygierczyk S and Waga JM, 1993. Plejstoceńskie osady w Samborcu koło Sandomierza (The Pleistocene sediments in Samborzec near Sandomierz). Geographia. Studia et Dissertationes 18, UŚ, 49-62 (in Polish)

Herenchuk KI, Kojnov MM and Cys' PM, 1964. Prirodnogeograficznyj podil lwiwskoho tapodislkoho ekonomiczeskych rajoniw (Natural-geographical division of the Lviv and Podillya economic districts). Wydawnictwo Lvivskoho Uniwersytetu: 220 pp (in Ukrainian).

Huntley DJ and Lamothe M, 2001. Ubiquity of anomalous fading in Kfeldspars and the measurement and correction for it in optical dating. Can. J. Earth Sci. 38(7): 1093-1106, DOI 10.1139/e01-013.

Jary Z, 2007. Zapis zmian klimatu w górnoplejstoceńskich sekwencjach lessowo-glebowych w Polsce i w zachodniej części Ukrainy (Record of Climate Changes in Upper Pleistocene loess-soil sequence in Poland and western part of Ukraine). Promotor Media Wydawnictwo, Wrocław: 136 pp (in Polish). 
Juvigné EH and Wintle AG, 1988. A new chronostratigraphy of the Late Weichselian loess units in Middle Europe based on thermoluminescence dating. Eiszeitalter und Gegenwart, 38: 94-105.

Komar M, Łanczont M and Madeyska T, 2009. Spatial vegetation patterns based on palynological records in the loess area between the Dnieper and Odra rivers during the last interglacial-glacial cycle. Quaternary Intnational 198(1-2): 152-172, DOI 10.1016/j.quaint.2008.04.008

Koster AE, 2005. Recent advances in luminecence dating of Late Pleistocene (cold-climate) aeolian sand and loess deposits in western Europe. Permafrost and Periglacial Processes 16(1): 131-143, DOI 10.1002/ppp.512.

Kusiak J, 1995. Opis metody termoluminescencyjnej datowania osadów czwartorzędowych stosowanej w laboratorium TL Zakładu Geografii Fizycznej i Paleogeografii UMCS w Lublinie (Description of the thermoluminescence method used for dating the Quaternary deposits in the laboratory Department of Physical Geography and Palaeogeography, Maria Curie-Skłodowska University, Lublin). Geochronometria 13: 97-109 (in Polish).

Kusiak J, 2002. Problem wyboru procedury pomiarowej w analizie termoluminescencyjnej na przykładzie datowania profilu Zahvizdja (Selection of measurement method in the TL analysis on the basis of dating of the Zahvizdja profile). In: Madeyska T, ed., Lessy i paleolit Naddniestrza halickiego (Ukraina) (Loess and Palaeolithic of the Dniester River Basin, Halyč region (Ukraine)), Studia Geologica Polonica 119: 193-197 (in Polish).

Kusiak J, 2006. Lessy górnoplejstoceńskie Polski południowowschodniej i Ukrainy północno-zachodniej w świetle datowań termoluminescencyjnych (Upper Pleistocene loesses in southeastern Poland and north-western Ukraine in the light of thermoluminescence dating). Rozprawa doktorska, Archiwum UMCS: 131 pp (in Polish).

Kusiak J, 2007. True and anomalous TL dates from Late Pleistocene loess-palaeosol deposits at the Kolodiiv site (East Carpathian Foreland, Ukraine). Geological Quarterly 51: 167-172.

Kusiak J, 2008a. Kontekst stratygraficzny zastosowania różnych odmian metody termolumi-nescencyjnej $\mathrm{w}$ datowaniu lessów $\mathrm{z}$ terenu Polski południowo-wschodniej i Ukrainy północno-zachodniej (Stratigraphic context of the application of different variants of thermoluminescence method to dating of loesses from the southeastern Poland and northwestern Ukraine). Annales UMCS sec.B 63: 21-60 (in Polish).

Kusiak J, 2008b. Lessy górnoplejstoceńskie Polski południowowschodniej i Ukrainy północ no-zachodniej w świetle datowań termoluminescencyjnych (Upper Pleistocene loesses in southeastern Poland and north-western Ukraine in the light of thermoluminescence dating). In: Materiaty $V$ Seminarium Lessowego $X V$ Seminarium Polsko-Ukraińskiego "Zapis zmian środowiskowych w późnoplejstoceńskich sekwencjach lessowo-glebowych" (Materials of $5^{\text {th }}$ Loess Seminar $15^{\text {th }}$ Ukrainian-Polish Seminar ,,Record of environment changes in Upper Pleistocene loess-soil sequences Wrocław - Srebrna Góra, 16-20 September 2008 (in Polish).

Kusiak $J$ and Lanczont M, 2002. New results of TL dating of the less profile at Polanów Samborzecki with use of the optical filters BG28 and UG-11. Geochronometria 19: 1-6.

Kusiak J, Łanczont M, Bogucki (Boguckyj) A and Wojtanowicz J, 2002. Divergence in the TL dating resulting from different methods of equivalent dose determination. Geochronometria 21: 27-32.

Kusiak J, Łanczont M and Wilgat M, 2007. TL ages of loesses from the last two glacials in SE Poland. Geochronometria 27: 33-40, DOI 10.2478/v10003-007-0010-5.

Lang A, Hatte C, Rousseau D-D, Antoine P, Fontugne M, Zöller L, Hambach U, 2003. High-resolution chronologies for loess: comparing AMS ${ }^{14} \mathrm{C}$ and optical dating results. Quaternary Science Reviews 22(10-13): 953-959, DOI 10.1016/S0277-3791(03)000350.

Lindner L, 1991. Stratigraphy of main Pleistocene loess horizons and paleosols in mid-eastern Europe. Acta Geologica Polonica 41(12): $85-100$
Lindner L and Prószyński M, 1979. Geochronology of the Pleistocene deposits exposed at Wąchock, nothern part of the Holy Cross Mts. Acta Geologica Polonica 29(1): 121-132.

Lindner L, Wojtanowicz J and (Bogucki) Bogutsky AB, 1998. Main stratigraphic units of the Pleistocene in southeastern Poland and northwestern Ukraine, and their correlation in western and mideastern Europe. Geological Quarterly 42(1): 73-86.

Lindner L, Bogucki A, Chlebowski R and Gożik P, 2004. Znaczenie występowania glin lodowcowych $\mathrm{w}$ reperowych profilach lessowych Polski i Ukrainy (The importance of glacial till occurrence in loess type sections of Poland and Ukraine). Przeglad Geologiczny 52(4): 331-335 (in Polish).

Lindner L and Marks L, 2008. Pleistocene stratigraphy of Poland and its correlation with stratotype sections in the Volhynian Upland (Ukraine). Geochronometria 31: 31-37, DOI 10.2478/v10003-0080014-9.

Łanczont M and Bogucki (Boguckyj) AB, 2002. Badane profile lessowe i stanowiska paleolit-tyczne Naddniestrza Halickiego (The examined loess sites in the Halyč Prydnistrov'ja region). In: Madeyska T, ed., Lessy i paleolit Naddniestrza halickiego (Ukraina) (Loess and Palaeolithic of the Dniester River Basin, Halyc region (Ukraine)). Studia Geologica Polonica 119: 33-181 (in Polish).

Łanczont M and Madeyska T, 2005. Environment of the East Carpathian Foreland during periods of Palaeolithic man's activity. Catena 59(3): 319-340, DOI 10.1016/j.catena.2004.09.003.

Łanczont $\mathrm{M}$ and Wojtanowicz J, 2005. Zagadnienia glacjalne i peryglacjalne przedpola Karpat w świetle badań profilu Zarzecze (Polska SE) (Glacial and periglacial problems of the Carpathian Foreland in the light of the investigations of the Zarzecze profile (SE Poland)). Annales UMCS 60(3) sec. B 47-62 (in Polish).

Łanczont M and Bogucki (Boguckyj) A, 2007. High-resolution terrestrial archive of the climatic oscillation during Oxygen Isotope Stages 5-2 from the unique loess-paleosol sequence at Kolodiiv (East Carpathian Foreland, Ukraine). Geological Quarterly 51(2): 105-126.

Łanczont M, Fedorowicz S, Kusiak J, Bogucki (Boguckij) A and Sytnyk Aleksandr, 2009. TL age of loess deposits in the Yezupil I Palaeolithic site on the upper Dniester River (Ukraine). Geologija $51(3-4): 86-96$

Martinson DG, Pisias NG, Hays JD; Imbrie JD, Moore TC, Shackleton NJ, 1987. Age Dating and the orbital theory of the ice ages: development of a high-resolution 0 to 300,000-year chronostratigraphy. Quaternary Research 27(1): 1-29, DOI 10.1016/00335894(87)90046-9.

Maruszczak H, 1972. Podstawowe cechy genetyczne i stratygraficzne lessów Polski południowo-wschodniej (Main genetic and stratigraphic features of loesses in south-eastern Poland). In: Maruszczak H, ed., Przewodnik sympozjum krajowego "Litologia i stratygrafia lessów w Polsce" (Guide-book of national symposium "Lithology and stratigraphy of loesses in Poland"), Wydawnictwo Geologiczne, Warszawa: 89-137 (in Polish).

Maruszczak H, 1994. Korelacja chronostratygraficzna lessów Polski Południowej i Ukrainy Północno-Zachodniej (Chronostratigraphic correlation of loesses in southern Poland and north-western Ukraine). Przeglad Geologiczny 42(9): 728-733 (in Polish).

Mejdahl V, 1986. Thermoluminescence dating of sediments. Radiation Protection Dosimetry 17(1-4): 219-227.

Mojski JE, 1968. Zarys stratygrafii zlodowacenia północnopolskiego (bałtyckiego) w północnej i środkowej części Polski (Outline of the stratigraphy of north Polish glaciation in North and Middle Poland). Prace Geograficzne IG PAN 74: 37-64 (in Polish).

Mojski JE, 1993. Europa w plejstocenie - ewolucja środowiska przyrodniczego (Europe in Pleistocene - evolution of natural environment). PAE, Warszawa (in Polish).

Mojski JE, 1999. Drobne jednostki stratygraficzne piętra wisły w obszarze perybałtyckim (Small stratigraphic units of Vistulian in the Peribaltic area). Przegląd Geologiczny 47(3): 247-254 (in Polish).

Nawrocki J, Bogucki (Boguckyj) A, Łanczont M, Kusiak J and Werner T, 2003. Paleomagnetyczne podstawy podziału i korelacji chronostratygraficznej lessów vistuliańskich Wyżyny Wołyńskiej (Palaeomagnetic basis of chronostratigraphic division and correlation 
of the Vistulian loesses in the Volyn Upland). In: Materiaty XII ukraińsko-polskiego seminarium terenowego „Stratygraficzna korelacja lessów i osadów lodowcowych Ukrainy i Polski” 15-19 września 2003 (in Polish).

Oczkowski HL, Przegiętka KR, Lankauf KR and Szmańda JB, 2000. Gamma spectrometry in thermoluminescence dating. Geochronometria 18: 57-62.

Paepe R and Vanhoorne R, 1967. The Stratigraphy and Palaeobotany of the Late Pleistocene in Belgium. Verhandelingen bij de Geologische Kaart en de Mijnkaart van België 8: 1-95.

Poręba G and Fedorowicz S, 2005. Gamma spectrometry for OSL and TL dating of loess deposits at Dybawka and Tarnawce (SE Poland), Geochronometria 24: 27-32.Prescott JR and Hutton JT, 1988. Cosmic ray and gamma ray dosimetry for TL and ESR. International Journal of Radiation Applications and Instrumentation. Part D. Nuclear Tracks and Radiation Measurements 14(12): 223-227, DOI 10.1016/1359-0189(88)90069-6.

Prescott JR and Hutton JT, 1994. Cosmic ray contributions to dose rates for luminescence and ESR dating: large depths and long-term time variations. Radiation Measurements 23(2-3): 497-500, DOI 10.1016/1350-4487(94)90086-8.

Prószyńska-Bordas H, Stańska-Prószyńska W and Prószyński M, 1987. Termoluminescencyjne wskaźniki wieku lessów i gleb kopalnych z przekroju w Odonowie (metoda i wyniki laboratorium warszawskiego) (Thermoluminescence indicators of age of loesses and paleosols from the Odonów profile (Warsaw laboratory method and results)). Sprawozdania z badań naukowych KBN 7: 16-29 (in Polish).

Roucoux KH, Tzedakis PC, Frogley MR, Lawson IT and Preece RC, 2008. Vegetation his-tory of the marine isotope stage 7 interglacial complex at Ioannina, NW Greece. Quaternary Science Reviews 27(13-14): 1378-1395, DOI 10.1016/j.quascirev.2008.04.002.

Rousseau D-D, Zöller L and Valet J-P, 1998. Late Pleistocene climatic variations at Achen-heim, France, based on a magnetic susceptibility and TL chronology of loess. Quaternary Research 49(3): 255265, DOI 10.1006/qres.1998.1972.

Rousseau D-D, Antoine P, Hattė C, Lange A, Zöller L, Fontugne M, Ben Othman D, Luck JM, Moine O, Labonne M, Bentaleb I and Jolly D, 2002. Abrupt millennial climatic changes from Nussloch
(Germany) Upper Weichselian eolian records during the Last Glaciation. Quaternary Science Reviews 21(14-15): 1577-1582, DOI 10.1016/S0277-3791(02)00034-3.

Singhvi AK, Sharma Y.P and Agrawal DP, 1982. Thermoluminescence dating of sand dunes in Rajastan, India. Nature 295(5847): 313315 , DOI 10.1038/295313a0.

Szelkoplyas WN and Christoforowa TF, 1987. Sledy rannieplejstocenowych oledenenii na territorii Ukrainy (Traces of Early Pleistocene glaciations in the territory of the Ukraine). Naukowa Dumka: 7-14 (in Ukrainian).

Szelkoplyas WN, Christoforowa TF, Palienko WP, Morozow GW, Maruszczak H, Lindner L, Wojtanowicz J, Butrym J and Bogucki (Boguckij) AB, 1985. Chronologija obrazowanii lesowoj i lednikowoj formacji zapadnoj czasti USSR i sopredelnych territorii (Chronology of loess and glacial deposits in the western part of the Soviet Union and adjoining areas). Institut Geologicheskich Nauk AN USSR Preprint 85-18: 1-51 (in Ukrainian).

Thompson GW and Goldstein LS, 2006. A radiometric calibration of the SPECMAP time scale. Quaternary Science Reviews 25(23-24): 3207-3215, DOI 10.1016/j.quascirev.2006.02.007.

Van den Haute P, Frechen M, Buylaert J-P, Vandenberghe D and De Corte F, 2003. The Last Interglacial palaeosol in the Belgian loess belt TL age record. Quaternary Science Reviews 22(10-13): 985990, DOI 10.1016/S0277-3791(03)00023-4.

Veklich MF, 1982. Paleoetapnosts y stratotypy pochoronnykh formatsy verkhnego kayno-zoya (Palaeostages and stratotypes of the Upper Cainozoic fossil formations). Naukova Dumka: 1-208 (in Ukrainian).

Veklich MF (ed.), 1993. Stratigraficheskaya shema chetvertichnych otlozheniy Ukrainy (Stratigraphical framework of Quaternary deposits of Ukraine). State Committee for Geology of Ukraine, Kiev (in Russian).

Wintle AG, 1987. Themoluminescence dating of loess. Catena Supplement 9: 103-115.

Zöller L, Rousseau D-D, Jäger KD and Kukla G, 2004. Last integlacial, Lower and Middle Weichselian - a comparative study from the Upper Rhine and Thuringian loess areas. Zeitschrift für Geomorphologie Neue Folge 48: 1-14. 